\title{
Imported or Home Grown? The 1992-3 EMS Crisis ${ }^{1}$
}

\author{
Barry Eichengreen Alain Naef
}

November 4, 2021

\begin{abstract}
Using newly assembled data on foreign exchange market intervention, we construct a daily index of exchange market pressure during the 1992-3 crisis in the European Monetary System, allowing us to pinpoint when and where the crisis was most severe. Our analysis focuses on a neglected factor in the crisis: the role of the weak dollar in intra-EMS tensions. We provide new evidence of the contribution of a falling dollar-Deutschmark exchange rate to pressure on EMS currencies.
\end{abstract}

Keywords: Foreign exchange market intervention, European Monetary System, currency crisis, ERM.

JEL: F31, E5, N14, N24

\footnotetext{
${ }^{1}$ University of California and Banque de France, respectively. Views in this paper are not the opinion of the Banque de France or the Eurosystem. Our intervention data come from publicly available archives and not the Banque de France. We are grateful to the Bank of England and Bundesbank archives for their cooperation and to Gaurav Gandhi, Damien Bonnot and Muriel Demottais for excellent research assistance. Much of the work was undertaken while Naef was a postdoctoral fellow at UC Berkeley. Helpful comments were provided by Marc Adam, William Allen, Zeynep Alraqeb, Michael Bordo, Oliver Bush, Sergio Castellanos-Gamboa, Rafael Cezar, Michael Curran, Devika Dutt, Jeffrey Frankel, Daniel Gros, Max Harris, Simon Hinrichsen, Owen Humpage, Harold James, Camille Macaire, Craig MacMahon, David Marsh, Clément Marsilli, Charles Wyplosz and participants in the Berkeley Economic History Lunch, seminars at Villanova and Oxford Universities the Economic History Society annual conference, the Financial History seminar, and the Paris School of Economics/Banque de France seminar. Eichengreen thanks the Clausen Center at the University of California, Berkeley. Naef thanks the Swiss National Science Foundation (grant number P2SKP1_181320) for funding.
} 


\section{Introduction}

The 1992-3 crisis in the Exchange Rate Mechanism of the European Monetary System was a seminal moment in Europe's monetary history. It underscored the fragility of pegged exchange rates and in so doing reinforced the commitment of European Union member states to complete the transition to monetary union. ${ }^{2}$

Yet three decades on there is no consensus about the causes of the crisis. The literature, which is substantial, focuses on events internal to Europe. German reunification entailed an increase in deficit spending in that country, mainly on Germany's own products. It therefore required a higher price of German relative to other European goods (Branson 1993). But with the Bundesbank pushing back against an acceleration in German inflation, and with real wage resistance limiting the scope for deflation in other countries, the only mechanism for this adjustment was a change in European exchange rates against the Deutschmark (DM), as brought about by the crisis. In this context, the Bundesbank's stubborn refusal to cut interest rates in order to relieve the pressure on other European central banks was a failure of international cooperation (Buiter, Corsetti and Pesenti 2001).

Other accounts (e.g. Tietmeyer 1998) blame not German reunification or the Bundesbank but chronic competitiveness problems in other countries. Sterling was overvalued at the parity at which it entered the Exchange Rate Mechanism (ERM) in 1990. Italian debts and deficits were too high. Banking systems were insolvent in the Scandinavian countries that shadowed the ERM. ${ }^{3}$ Still other authors (Eichengreen and Wyplosz 1993) put the onus on political events, such as Denmark's rejection of the Maastricht Treaty on June 2, 1992, which made it seem less likely that monetary union would in fact occur, in turn weakening the incentive for other countries to maintain the high interest rates needed to hold their exchange rates stable within the ERM and qualify for euro adoption. ${ }^{4}$

This focus on events in the crisis countries and region contrasts with the literature on other crises, which adds a role for external factors and emphasizes their importance. Analyses of historic currency and financial crises, such as that of 1873, focus on events in the major international financial centers (Davies 2018). Treatments of the 1980s Latin American debt and currency crises point to the role of sharp increases in U.S. interest rates in precipitating a sudden stop of capital flows to emerging markets (ECLAC 1996). The common creditor channel, whereby external creditors whose balance sheets are impaired as a result of investments in one country, draw down their exposure to others, is frequently cited as a channel for contagious

\footnotetext{
${ }^{2}$ As they of course did in 1999. We say "reinforced" because the Delors Report and Maastricht Treaty preceded the crisis. The statement in the text could be qualified by adding "most EU members," since the UK and Denmark obtained opt outs.

${ }^{3}$ Scandinavian central banks were not members of the EMS, but they pegged their currencies to the DM or ecu, albeit without the support from other European central banks afforded to formal members of the system. We include them in our analysis because contemporary accounts clearly saw developments in these countries as highly relevant to the fate of the ERM.

${ }^{4}$ One of the so-called Convergence Criteria in the Maastricht Treaty governing entry was that countries should maintain their currencies stable within the ERM "without undue tensions."
} 
currency crises (Kaminsky and Reinhart 2000, Pesenti and Tille 2000, Mitchener and Weidenmier 2008).

Here we similarly add a role for developments outside Europe, specifically U.S. dollar weakness, in heightening monetary tensions within the EMS. Dollar weakness was associated with flows from the greenback to the DM, the closest substitute for the U.S. currency. As the DM rose against other ERM currencies, the latter were at risk of breaching their bilateral divergence margins. This phenomenon was recognized at the time; it was known as "dollar-Deutschmark polarization."6 The implication was that the EMS crisis was imported, in substantial part, and not only home grown.

We provide two types of evidence for the role of the dollar. First, we draw on primary and secondary sources to document that contemporaries were aware and concerned about dollar weakness and dollar/DM polarization. Second, we show statistically that movements in the dollar/DM exchange rate explain a significant fraction of the pressure on EMS currencies in this period. The impact of the dollar/DM rate was large, both absolutely and relative to the internal factors (inter alia Bundesbank policy) emphasized in earlier literature. Depreciation of the dollar from $\$ 1.6$ to $\$ 1.4 \mathrm{DM}$, not an atypical move in the period, has fully four times the impact on exchange market pressure of a 100 basis point increase in the Bundesbank policy rate. This highlights the importance of the channel emphasized here.

Our statistical analysis is based on new data on foreign-exchange market intervention by EMS central banks from 1986 to 1995, years spanning the crisis. We construct daily measures of exchange-market pressure. This allows for greater precision in distinguishing sources of pressure on ERM exchange rates, compared to previous studies that used monthly or even lower frequency data and/or were forced to neglect foreign-exchange market intervention. Our data were assembled by European central banks on a confidential basis; we are able to access them because of a change in policy governing the delay in making available to researchers material in the British official archives, including those of the Bank of England, which shortened the period of delay from 30 to 20 years.

A few previous studies have touched on the role of the dollar in the crisis (see e.g. Harmon and Heisenberg 1993, Edison and Kole 1995, Eichengreen 2002, Truman 2002, James 2012, Gros 2014 and James 2020), but none has developed this point fully, much less provided statistical evidence. There is also a handful of studies of dollar/Deutschmark polarization (Brown 1979, Giavazzi and Giovannini 1989, Haldane and Hall 1991, Forder and Hurn 2003), but these precede or otherwise do not link the phenomenon to the 1992-3 crisis.

\footnotetext{
${ }^{6}$ Exactly why the DM was a closer substitute than other EMS currencies for the dollar need not detain us here. Giavazzi and Giovannini (1989) suggest that the market in DM-denominated securities was larger and more liquid than markets for other European securities, in this respect more closely resembling the dollar. Habib and Stracca (2011) point to low public debt and low external vulnerability as well as to high market liquidity. Contemporaries such as Karl Otto Pohl pointed to the Bundesbank's commitment to price stability (Mee 2019).
} 
Section 2 introduces and describes our data, after which Section 3 uses them to construct a composite measure of exchange-market pressure, which we then use in Section 4 to provide a new perspective on the crisis. ${ }^{10}$ In Sections 5 and 6 we present our evidence of the role of dollar weakness, after which Section 7 concludes. A set of (online) appendices describe the data, exchange market pressure measures, and econometric results in more detail, and provide institutional background on the EMS.

\section{Data}

Our data on foreign exchange intervention are from the Bank of England archives. We extracted more than 500,000 daily observations spanning 1986-1995 for all major European central banks. ${ }^{11}$ Interventions were recorded and summarized in daily reports by the dealers of the Bank, who oversaw purchases and sales of foreign exchange and related derivatives. ${ }^{12}$ The documents reflect reports received and tabulated of intervention by the Bank of England but also other central banks.

We have data for the central banks of the following EMS countries: Belgium, Denmark, France, Germany, Ireland, Italy, the Netherlands, Portugal, Spain and the UK. In addition, there are data for four non-EMS countries whose currencies were pegged to the ecu or the DM: Finland, Greece, Norway and Sweden. ${ }^{13}$ Bank of England records on intervention on the last five days of the crisis (at the end of July 1993) have not yet been declassified; we fill these in using the Bundesbank archives.

This information was shared by central banks through a process known as "the concertation." Concertation means mutual exchange of information. This exchange was a way for central banks to monitor use of their currency by other members. ${ }^{14}$ Brandner, Grech and Stix (2006) describe the timing as follows. Each day central banks reported purchases and sales of foreign exchange in four concertation rounds. The first round was at 9:30 a.m. and the last round was at 4:00 p.m, coincident with the London market close. ${ }^{15}$ "The intervention data are therefore cumulated intervention volumes for a time period of $24 \mathrm{~h}$, starting from 4:00 p.m. previous day until 4:00 p.m. today. Interventions undertaken after 4:00 p.m. are reported in the first concertation round the next day at 9:30 a.m. and are included in next day's intervention figure. At each concertation

\footnotetext{
${ }^{11}$ Brandner, Grech and Stix (2006) also used data from concertation protocols (these authors were associated with the Austrian financial ministry and central bank, enabling them to access confidential data), but for a shorter period and a smaller set of central banks.

${ }^{12}$ The full reference is 'Foreign Exchange and Gold Markets: Dealers' Regular Internal Reports,' 1986-1995, London, Archives of the Bank of England, references C8/66 to C8/110.

${ }^{13}$ Although the concertation data do not distinguish interventions in different currencies by the Bank of England, for all other central banks they do. Other documents released by the British government indicate that most Bank of England intervention was in DM. On Black Wednesday for example, other documentation shows that the $\$ 22$ billion of reserves expended by the Bank of England were in entirely in DM (see http://webarchive.nationalarchives.gov.uk/20130129110519/http:/www.hmtreasury.gov.uk/ukecon_eea_index.htm).

${ }^{14}$ It may have also discouraged offsetting interventions and avoided introducing volatility into the market.

${ }^{15}$ The Bundesbank Archives tell us that the two mid-day concertations were at 11:30 am and 2:15 pm.
} 
session, central banks had to supply the volumes of spot interventions in Community and nonCommunity currencies and other transactions leading to changes in reserves." ${ }^{16}$

Figure 1. 30-Day Moving Average of the Number of Central Banks Intervening per Day

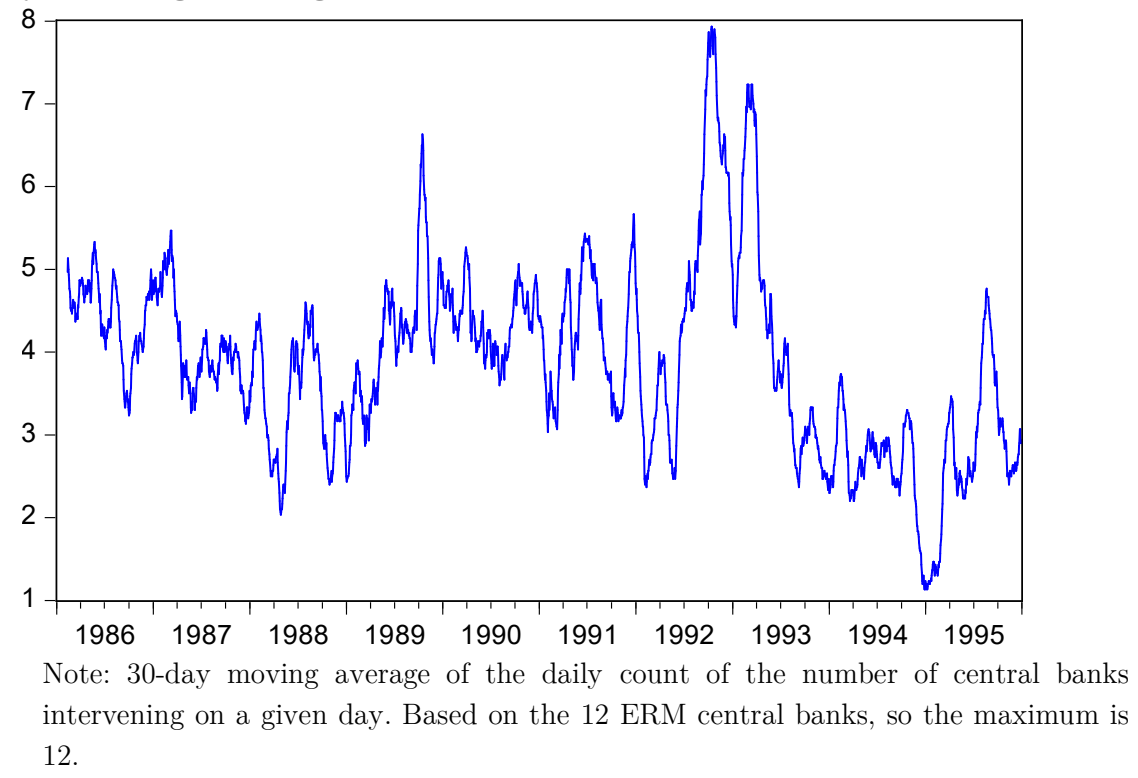

Concertation data were meant to be comprehensive. Consistent with Brander, Grech and Stix's reference to "spot interventions...and other transactions," we take these figures as capturing interventions in both spot and forward markets. These interventions should be interpreted as sterilized - that is, as offset by liquidity operations so as not to affect interest rates.

Figure 1 shows a 30-day moving average of the number of central banks intervening. It points to two peak periods: September 1992 (around the time of the French referendum on the Maastricht Treaty and "Black Wednesday," when sterling left the ERM), and February-March 1993, (a period that saw pressure on the currencies of Belgium, Denmark, Portugal and Spain). ${ }^{17}$

The final crisis of the system, in late-July-early-August 1993 does not show up in this 30-day moving average, since intervention was concentrated in only a few days. That final crisis does show up, however, when we consider the value of intervention. Figure 2 plots the daily average of the value of al DM interventions. The figure highlights the exceptional magnitude of interventions in 1992-1993 compared to the rest of the sample. The first peak was on September 16, 1992, Black Wednesday, when Britain left the ERM, spending $\$ 22$ billon, and when the Bank of Italy spent nearly $\$ 6$ billon in support of the lira. The second peak, as noted, was in July 1993, just prior to when ERM bands were widened in response to pressure on the French franc and other currencies.

Figure 2 shows the existence of substantial interventions even before the crisis. In particular, there were sizeable interventions by the Bank of France and Bank of England - in both directions

\footnotetext{
${ }^{16}$ Brandner, Grech and Stix (2006), p.583.

${ }^{17}$ The earlier peak in the series, in 1989, marks an episode late in the year when multiple central banks intervened to support their currencies (Galati and Melick 2002).
} 
- in 1986-7, around the time of the Plaza and Louvre Accords (agreements on the part of G5 countries to weaken and strengthen the dollar, respectively) and the last ERM general realignment, and somewhat smaller ones in 1989-90, an earlier period of dollar stress. ${ }^{18}$ The Bank of Italy intervened repeatedly to both support and restrain the lira. But those earlier interventions were sporadic, in the French and British cases, or small, in the Italian case. We then see large, persistent interventions in 1991-2 by Finland, Sweden and Italy, three of the first countries to feel the crisis. We see an even larger number of substantial, persistent interventions in the second quarter of 1992 when the crisis spreads.

Figure 2. Average DM Intervention by ERM countries, $\$ \mathrm{~m}$.

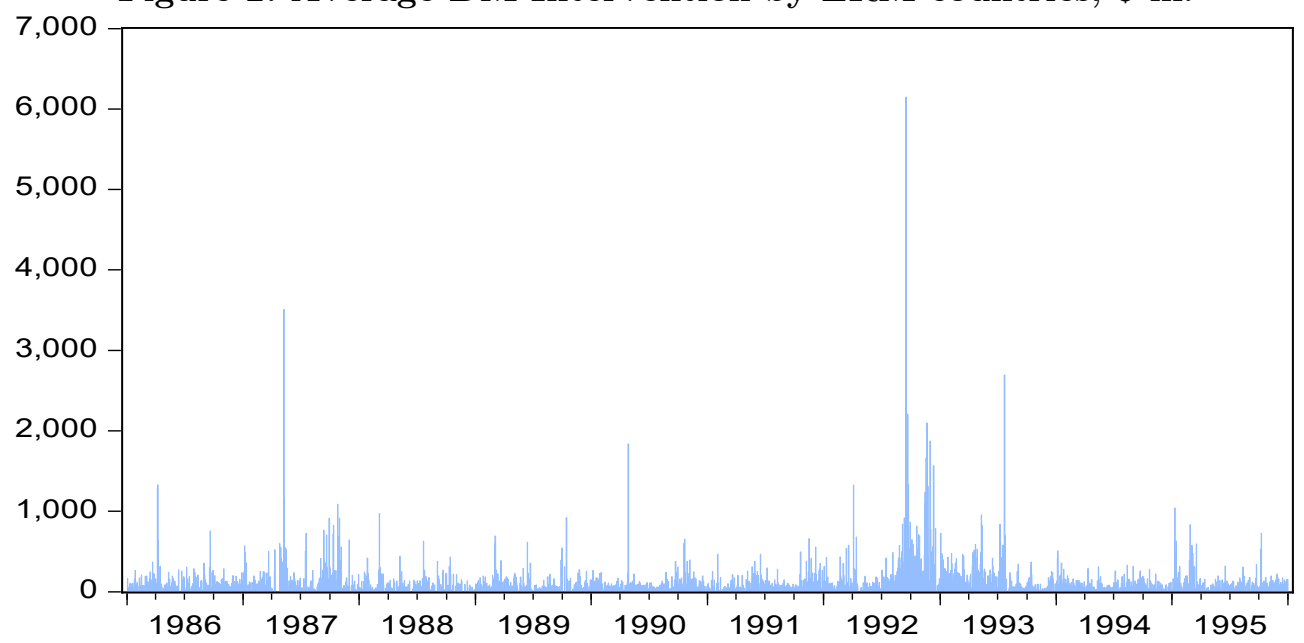

Note: Average size of all interventions in DM on a given day expressed in US dollars. The figure is the sum of the absolute value for intervention for each country and includes DM sales and purchases.

Figure 3 focuses on the crisis period, showing total net interventions by individual central banks. It highlights the magnitude of Sweden's interventions relative to the size of its economy and financial system but also absolutely. It highlights the magnitude of the intervention commitments of France, Italy and Spain. Much has been made of the extent of intervention by the Bank of England in September 1992. Figure 3 reminds us that it was not alone.

Another perspective is Table 1, which scales crisis-period interventions by domestic financial markets. Sweden's interventions seem even more extraordinary so scaled. Finland's interventions also stand out. Smaller on this scale but still extensive were interventions by the central banks of Spain, Portugal, Ireland and Denmark. Interventions by the Bank of Italy, the Bank of England and the Bank of France look more modest when scaled by liquid liabilities.

\footnotetext{
${ }^{18}$ The UK only entered the ERM in 1990. But 1987-88 was when the British government adopted a policy of shadowing the DM at the level of DM3 = £1, which led to some large purchases of DM by the Bank of England.
} 
Figure 3. Intervention Net Totals, June 2, 1992 -August 2, 1993 (\$ m.)

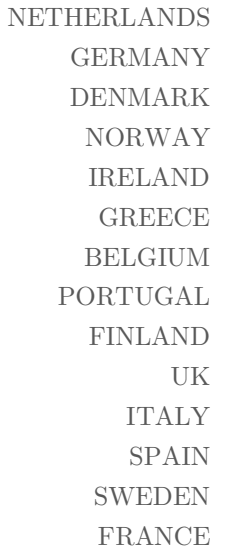

Source: Authors' calculation based on the Bank of England dealers' reports (C8).

Table 1. Interventions as a Share of Liquid Liabilities

\begin{tabular}{llll} 
& $\begin{array}{c}\text { Liquid Liabilities for 1992-93 } \\
\text { (million of 2000 dollars) }\end{array}$ & \multicolumn{1}{c}{$\begin{array}{c}\text { Overall intervention } \\
\text { during ERM crisis } \$ \\
\text { million) }\end{array}$} & Ratio \\
\hline Belgium & 256062 & -3514 & $1.4 \%$ \\
Denmark & 128698 & 4022 & $3.1 \%$ \\
France & 1150000 & -68892 & $6.0 \%$ \\
Germany & 1900000 & 13257 & $0.7 \%$ \\
Ireland & 36415 & -434 & $1.2 \%$ \\
Italy & 967744 & -32184 & $3.3 \%$ \\
Netherlands & 401047 & 18113 & $4.5 \%$ \\
Portugal & 117334 & -11644 & $9.9 \%$ \\
Spain & 553716 & -45473 & $8.2 \%$ \\
UK & 885553 & -20274 & $2.3 \%$ \\
Finland & 83152 & & $17.2 \%$ \\
Greece & 79567 & -14272 & $4.1 \%$ \\
Norway & 101909 & 3255 & $3.2 \%$ \\
Sweden & 141561 & 3255 & $40.1 \%$
\end{tabular}

Note: Aggregate intervention during the crisis period June 2, 1992 - August 1, 1993. *Data for Germany include DM operations with all other European currencies. The positive numbers for Germany and the Netherlands indicate the amount of purchases of other European currencies for DM and guilder. Source: Authors' calculation based on the Bank of England dealers' reports (C8) and FRED for liquid liabilities.

Table 1 also shows small interventions in support of other ERM currencies by the Bundesbank and the central banks of the Benelux countries. The obligations of countries whose currencies were approaching the top of their bands were formally the same as the obligations of central 
banks whose currencies were approaching the bottom, but the difference in the magnitude of restraining and defending interventions shows that this was not the practice. ${ }^{19}$

\section{Exchange Market Pressure}

We now construct an index of Exchange Market Pressure (EMP) for each country. The use of daily intervention data enables us to increase the periodicity of the index relative to previous studies using the change in reserves, which is typically available only on a monthly basis. In addition, intervention better captures pressure on the exchange rate, since reserves can change for reasons unrelated to the exchange rate and its management..$^{20}$ Reserves can be manipulated or window dressed, since central banks are aware that poor reserve data can affect sentiment adversely. ${ }^{21}$ Intervention data, being confidential, should be free of this problem.

We define EMP as:

$$
E M P=\frac{\Delta e_{t}-\mu_{e}}{\sigma_{e}}-\frac{\nabla r_{t}-\mu_{r}}{\sigma_{r}}-\frac{i n t-\mu_{i n t}}{\sigma_{i n t}}
$$

where $\Delta e_{t}$ is the change in exchange rate, $\nabla r_{t}$ the differential between the interest rate in a given country and Germany (where we consider central bank policy rates for marginal lending operations), and int is intervention. $\mu$ and $\sigma$ are means and standard deviations of the respective variables. Pressure (EMP) increases when the exchange rate depreciates, the central bank has to raise its policy interest rate relative to Germany (the ERM anchor country) and/or intervention in support of the currency is extensive. Each constituent of the index is expressed relative to its average to account for different scales and, following Eichengreen, Rose and Wyplosz (1995), normalized by its standard deviation to account for different average volatilities.

Normalizing the three constituents of the index by their respective standard deviations is not the only conceivable weighting scheme, though these are the weights most widely used in the literature, facilitating comparisons of our results with earlier work. Girton and Roper (1977), in contrast, attached equal weights to the constituents of their index, while Goldberg and Krogstrup (2018) derive their weights from a structural model of the balance of payments. ${ }^{22}$ As we describe below in the section on robustness, we obtain consistent results using several different weighting schemes.

\footnotetext{
${ }^{19}$ Recall our discussion of the Emminger Letter in Section 2 above.

${ }^{20}$ It is conceivable that some reported interventions reflected efforts to rebalance the currency composition of the reserve portfolio (to rebuild foreign currency reserves after a period of exchange rate weakness had passed) or efforts to assist other central banks in their efforts to rebuild their reserves, as opposed to attempts to actively influence the direction or rate of change of the exchange rate. Brander, Grech and Stix mention this as well. These operations would entail mainly sales of local currency, which we refer to as restraining intervention, and not the sale of foreign currencies, referred to as defending interventions, where most scholarly and popular interest centers on the latter.

${ }^{21}$ See Naef (2020a) on window dressing.

${ }^{22}$ In addition, Goldberg and Krogstrup cite yet additional papers that use still other variants of these weighting schemes.
} 
Figure 4 shows the average of EMP for nine ERM countries (excluding Germany, the DM being the reference currency in the constructions of the EMP index) and the three Nordics shadowing the system. ${ }^{23}$ It suggests a progressive buildup of pressure, peaking on Black Wednesday, 16 September, 1992. Pressure then drops, although there are subsequent spikes linked to crises in different countries. ${ }^{24}$ The spikes in 1991 reflect pressure on the currencies of Finland, Sweden and Portugal. ${ }^{25}$ In 1992, exchange market pressure is evident in a number of different countries, although the UK stands out. The further spike in 1993 was a French phenomenon.

We now use these indices to construct a new analytical narrative of the EMS crisis. ${ }^{26}$

Figure 4. Exchange Market Pressure Index (Average for 12 ERM countries)

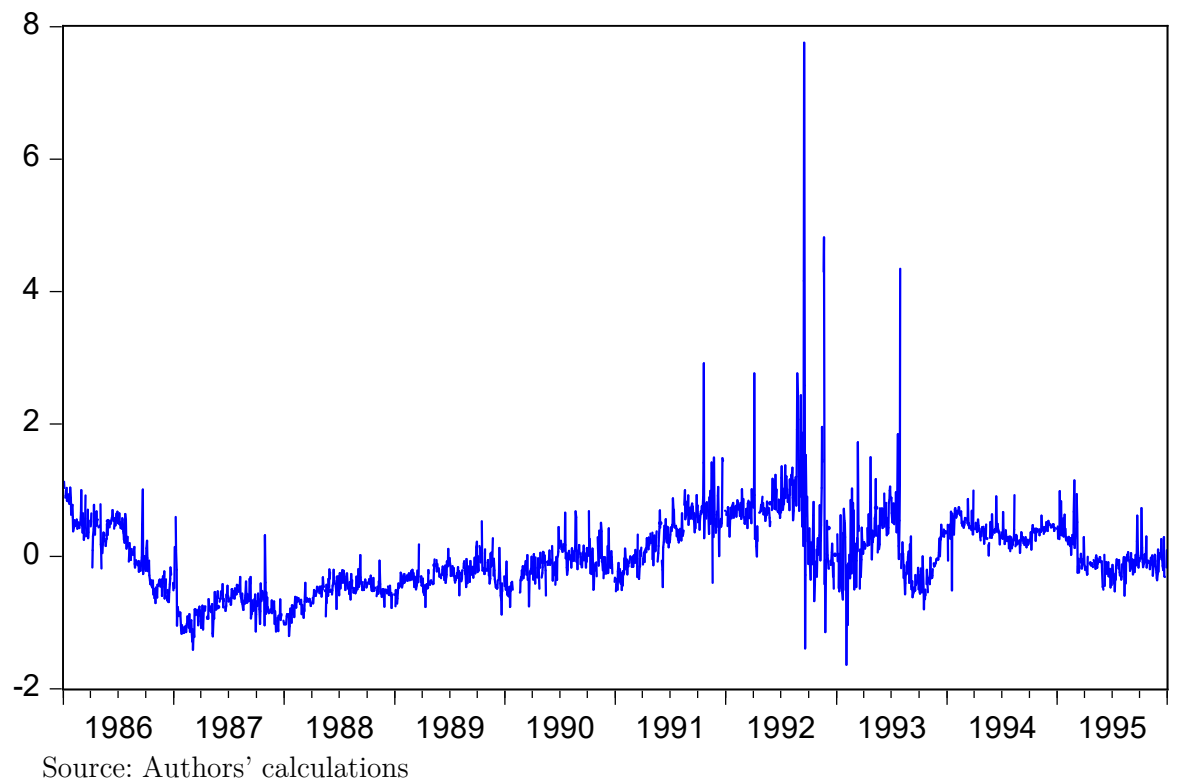

\section{Analytical Narrative of the Crisis ${ }^{27}$}

Most narratives date the start of the crisis as June $2^{\text {nd }}, 1992$, when Denmark rejected the Maastricht Treaty in a referendum..$^{28}$ Our indices, in Table 2, which lists the ten highest Europe wide values for EMP over the period, suggests that exchange rates already came under strain two months earlier. ${ }^{29}$ April 3, 1992 saw some of the highest levels of exchange market pressure prior to Black Wednesday, when the Bank of Finland and the Sveriges Riksbank intervened

${ }^{23}$ All data used in constructing and analyzing this series are described in Appendix A.

${ }^{24}$ The negative spike in February 1993 reflects a large obligatory intervention supporting the Danish krone by the Netherlands Bank (see below).

${ }^{25}$ Individual-country figures are in Appendix B.

${ }^{26}$ Earlier narratives are based on official reports from central banks and international organizations and on newspaper accounts. Our narrative is based instead on our daily indices of exchange market pressure.

${ }^{27}$ For additional background information on the EMS prior to the crisis, see Appendix C.

${ }^{28}$ Denmark was one of two countries, along with Ireland, required to hold a referendum on the Maastricht Treaty. France also held a referendum, although it had the option of treaty ratification by parliamentary vote, which would have required a three-fifth majority in both the Assembly and Senate.

${ }^{29}$ The first column shows the average Europe-wide value, subsequent columns individual country levels. 
heavily. Finland had experienced a bank-led credit boom following years of financial deregulation. ${ }^{30}$ Monetary policy then turned restrictive in 1989, when the central bank grew worried about financial excesses, and with the collapse of the Soviet Union, exports to Russia dropped by 70 per cent (Honkapohja and Koskela 1999). Combined with reunification-related increases in German interest rates (imported into Finland as a result of the exchange rate peg), boom turned to bust, precipitating a banking crisis in the autumn of 1991 and devaluation in December. But doubts about the stability of the banks remained, compounded by fears that devaluation only worsened banking-sector problems owing to the presence of currency mismatches on household and bank balance sheets. Hence the pressure in early 1992.

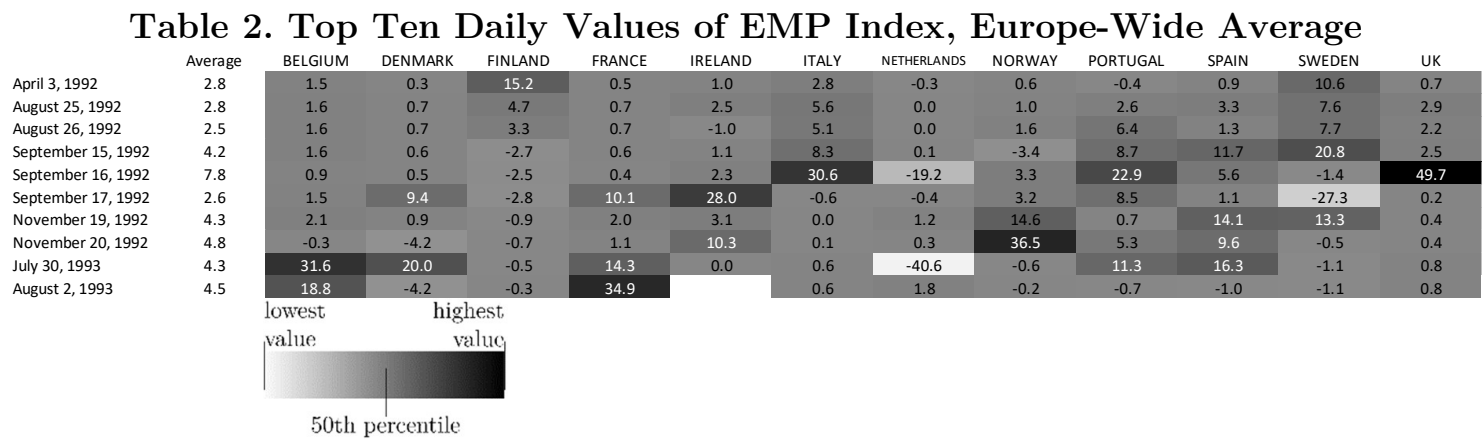

In Sweden, exchange market pressure in early April, while not as intense, was noticeable. Sweden was thought, rightly or wrongly, to compete with Finland on international markets and as suffering some of the same problems. Sweden too had deregulated its financial markets, experienced a credit boom, and saw a sharp rise in nonperforming loans as that boom turned to bust. There was also noticeable exchange market pressure on Italy, where concern centered not on the banking system but on macroeconomic imbalances, Italy being the major industrial country with the largest general government budget deficit and highest inflation. ${ }^{34}$

Conventional narratives point to the Danish "nej" on June $3^{\text {rd }}$ as a major shock. The outcome had not been forecast by opinion polls. It cast into doubt the transition to the Single Currency, raising questions about whether Italy had adequate incentive to implement the restrictive policies needed for the stability of the lira. Our evidence suggests downplaying the importance of the referendum. Doubts already existed earlier. Nor does June 3, 1992, following the Danish referendum, rank as one of our top 10 exchange market pressure days.

Still, the referendum reminded investors that monetary union and the exchange rate stability required to participate were not guaranteed, causing the Italian lira to fall and forcing the Bank of Italy to intervene. ${ }^{35}$ This made sense: Italy's weaknesses were macroeconomic in nature, something that the Maastricht Treaty's convergence criteria were tailored to address, and if

\footnotetext{
${ }^{30}$ Blank cells are holidays when the market was closed.

${ }^{34}$ Among all industrial countries, as distinct from the "major" industrial countries, only Greece had a larger budget deficit (a larger general government financial deficit including social insurance). The major-other country distinction follows the IMF's World Economic Outlook (May 1993), from where these data are taken.

${ }^{35}$ Pressure on the lira, as we measure it, tripled on June $3^{\text {rd }}$ from the previous day. The Danish krone itself does not appear to have been perceived as a vulnerable currency.
} 
there was going to be no monetary union, then there would be no related pressure for Italy to undertake macroeconomic adjustment. ${ }^{36}$

In contrast, the pound sterling, which retrospective accounts assert was significantly overvalued coming into the summer of 1992, does not appear to have experienced significant exchangemarket pressure at this point in time. ${ }^{37}$ In contrast, the Irish punt came under pressure, perhaps reflecting the fact that Ireland was the next place where a referendum was scheduled and fears, if the Irish voted no, that the punt would come untethered from the ERM. ${ }^{38}$ When we run BaiPerron tests for structural breaks in individual country EMP series in 1992, June $2^{\text {nd }}$ is a significant break for both Italy and Ireland (the only such breaks before their devaluations late in the year). ${ }^{39}$

Pressure on the lira but now also on the peseta and escudo mounted in the course of August. On September 3-4, Germany stepped in with its largest intervention of the crisis, spending over $\$ 4$ billion to support the lira. The Bank of Italy increased its interest rate by 1.75 percentage points, the largest increase in 11 years. These actions set the stage for an acrimonious Economic and Financial Affairs Council (ECOFIN) meeting on September 4-5, at which British Chancellor Norman Lamont harangued Bundesbank President Helmut Schlesinger for further reductions in German rates. The most Schlesinger was prepared to concede was that there was no immediate need for German rates to increase..$^{40}$ Lamont, in his post-meeting press briefing, characterized the German position as a firm promise not to raise rates.

While this assertion reassured investors about ERM currencies such as the lira that might also receive support from the system's strong currency countries, it heightened their worries about non-ERM currencies that were shadowing the DM or the ecu that could look for no formal support. ${ }^{41}$ Pressure on the markka had died down following the Bank of Finland's massive interventions in early April. In July and August, however, pressure resumed, forcing the Bank to again intervene to support its ecu peg. After spending $\$ 5.4$ billion in just five days, the government abandoned the peg on September $8^{\text {th }}$. Once more, Italy was collateral damage: Germany, the Netherlands and Belgium all intervened to prevent the lira from breaking through its bilateral fluctuation bands.

At this point, currency traders again turned their attention on Sweden. The Riksbank defended the krona by raising interest rates to stratospheric levels and, like its neighbour, by intervening in the foreign exchange market. As was seen in Table 1, Sweden spent $\$ 56$ billion on intervention

\footnotetext{
${ }^{36}$ We also see pressure on the Portuguese escudo and Irish punt around the time of the Danish referendum.

${ }^{37}$ The absence of exchange market pressure but also worries about overvaluation at this time are noted by James (2020), p.287.

${ }^{38}$ There were also worries about the systematic implications: the Financial Times wrote that if "the Irish follow the Danes and vote 'no', there would seem little alternative to scrapping the treaty." "One in four Irish voters undecided about Maastricht", Financial Times (18 June 1992), p.1.

${ }^{39}$ It is a break for these two countries but no others. These tests are run with 5 breaks as a maximum, $15 \%$ and a $5 \%$ significance level (which are standard settings). The EMP is regressed against a constant to see for changes in average levels of pressure. The data range is the whole of 1992. Many countries do not yield any breaks.

${ }^{40}$ James (2012), p.352.

${ }^{41}$ James (2020), pp.293-4.
} 
in the crisis, the most of any European country. But there were problems in the banking system: the government had been forced to inject capital into two banks in late 1991 and then, in early September 1992, to issue a blanket guarantee of the obligations of Gota Bank, a systemically significant institution. Whether the banking system and, hence, the currency could withstand the strain of triple-digit interest rates was, at best, uncertain.

With Sweden mounting this stout defense, currency traders turned once more to the lira. On Friday, 11 September, 1992 the currency was subject to unprecedented levels of pressure. On Saturday, the German finance ministry and the Bundesbank agreed that the German central bank would refrain from further intervention on behalf of the lira. ${ }^{42}$

Italy was left with no choice. On Sunday, European policy makers announced a 3.5 per cent devaluation of the lira and 3.5 per cent revaluation of other ERM currencies (a cosmetic way of devaluing the lira by 7 per cent). Other countries, including the UK, refused to follow, making this a less than general realignment. As its contribution, the Bundesbank cut interest rates (the discount rate by 50 basis points, the Lombard rate by 25$)$.

This package was criticized as inadequate for the small size of the German interest rate cut and the fact that no other countries accompanied Italy in realigning. In addition, the outcome was reached irregularly, without a formal meeting of the Monetary Committee of the European Council. Other governments were reluctant to convene such a meeting for fear that they could come under pressure from Germany and the Netherlands to accompany Italy in devaluing against the DM. Table 3, a heat map for the period around Black Wednesday, suggests that the others that should have accompanied Italy were Spain and Portugal, two countries that, more than the UK, competed in the same product space and saw their competitiveness negatively affected by the lira's devaluation.

The French referendum on the Maastricht Treaty was looming on September $20^{\text {th }}$, and polls suggested that the outcome would be razor thin (Lewis-Beck and Morey 2007). The Bank of England and UK Treasury were preparing to mount a defense of sterling when the markets opened on Monday, September $14^{\text {th }}{ }^{43}$ But British officials were not prepared for some out-ofschool remarks by Bundesbank President Helmut Schlesinger, to reporters from Handelsblatt and the Wall Street Journal on September $15^{\text {th }}$ and published the following day. Schlesinger observed that a more comprehensive realignment would have been better and that further exchange market pressure could not be ruled out. Schlesinger's comments evidently planted doubts in the minds of investors about whether the Bundesbank was prepared to engage in unlimited interventions to prevent the DM from breaching its bilateral limits against other currencies.

${ }^{42}$ The German institutions invoked their authority under the Emminger letter. The Bundesbank immediately conveyed the news to a shocked Bank of Italy governor Carlo Ciampi. James (2012), p.356.

${ }^{43}$ See Keegan, Marsh and Roberts (2017). Preparations would have entailed prearranging purchases of sterling, since transactions were still conducted by mainly by telephone and were therefore limited by the number of phone lines in the Bank of England's dealers' room. Reuters had launched a matching server in London some months earlier to trade dollar/sterling, dollar/mark and dollar/yen but as yet had only a limited number of bank customers (Eichengreen 2020). 
Table 3. EMP Heat Map around Black Wednesday, September 16, 1992

\begin{tabular}{|c|c|c|c|c|c|c|c|}
\hline & Average & FRANCE & IRELAND & ITALY & PORTUGAL & SPAIN & UK \\
\hline August 20, 1992 & 1.1 & 0.9 & 0.2 & 1.0 & 1.9 & 0.7 & 2.1 \\
\hline August 21, 1992 & 2.0 & 0.6 & 0.7 & 0.9 & 8.0 & -0.3 & 1.9 \\
\hline August 24, 1992 & 2.6 & 1.3 & 1.0 & 1.5 & 8.8 & 0.8 & 2.4 \\
\hline August 25, 1992 & 2.9 & 0.7 & 2.5 & 5.6 & 2.6 & 3.3 & 2.9 \\
\hline August 26, 1992 & 2.5 & 0.7 & -1.0 & 5.1 & 6.4 & 1.3 & 2.2 \\
\hline August 27, 1992 & 2.9 & 0.8 & 1.2 & 3.8 & 3.1 & 7.9 & 1.0 \\
\hline August 28, 1992 & 2.7 & 0.7 & 4.1 & 6.5 & 1.8 & 2.0 & 1.3 \\
\hline August 31, 1992 & 1.1 & 0.7 & 1.2 & 1.0 & 1.8 & 1.2 & 1.0 \\
\hline September 1, 1992 & 1.6 & 0.7 & 1.2 & 1.0 & 4.5 & 1.2 & 1.1 \\
\hline September 2, 1992 & 1.5 & 0.7 & 3.2 & 1.0 & 2.2 & 1.2 & 0.9 \\
\hline September 3, 1992 & 1.7 & 0.8 & 1.2 & 3.5 & 2.4 & 0.7 & 1.4 \\
\hline September 4, 1992 & 3.0 & 0.9 & 1.2 & 9.4 & 4.4 & 0.9 & 1.4 \\
\hline September 7, 1992 & 1.1 & 0.8 & 1.9 & 0.3 & 1.8 & 0.7 & 1.3 \\
\hline September 8, 1992 & 2.6 & 0.8 & 2.8 & 0.8 & 7.9 & 2.1 & 0.9 \\
\hline September 9, 1992 & 1.0 & 0.8 & 1.2 & 0.3 & 1.8 & 0.7 & 0.9 \\
\hline September 10, 1992 & 4.8 & 0.7 & 1.3 & 10.7 & 8.4 & 6.5 & 0.9 \\
\hline September 11, 1992 & 3.3 & 0.8 & 1.3 & 13.2 & 2.9 & 0.7 & 0.9 \\
\hline September 14, 1992 & 0.7 & 1.6 & 0.7 & -2.1 & 1.8 & 0.8 & 1.5 \\
\hline September 15, 1992 & 5.5 & 0.6 & 1.1 & 8.3 & 8.7 & 11.7 & 2.5 \\
\hline September 16, 1992 & 18.6 & 0.4 & 2.3 & 30.6 & 22.9 & 5.6 & 49.7 \\
\hline \multicolumn{8}{|c|}{ Black Wednesday } \\
\hline September 17, 1992 & 7.9 & 10.1 & 28.0 & -0.6 & 8.5 & 1.1 & 0.2 \\
\hline September 18, 1992 & 2.3 & 10.8 & -3.3 & -0.6 & 5.0 & 1.6 & 0.3 \\
\hline September 21, 1992 & 1.1 & 3.3 & 0.9 & -0.5 & 0.7 & 1.9 & 0.1 \\
\hline September 22, 1992 & 5.1 & 14.2 & 5.0 & -0.6 & 0.8 & 10.8 & 0.2 \\
\hline September 23, 1992 & 2.6 & 7.6 & 6.7 & -0.5 & 1.2 & 0.0 & 0.3 \\
\hline \multirow[t]{2}{*}{ September 24, 1992} & 0.9 & 0.5 & 4.0 & -0.5 & 1.5 & -0.1 & 0.3 \\
\hline & & $\begin{array}{l}\text { lowest } \\
\text { value }\end{array}$ & $\begin{array}{l}\text { highest } \\
\text { value }\end{array}$ & & & & \\
\hline
\end{tabular}

Schlesinger may have been unaware that he would be quoted. Alternatively, he may have been responding to Lamont's earlier provocation. Some commentators downplay the remarks as disclosing nothing that investors did not already know and attribute the subsequent crisis to macroeconomic and financial imbalances, not to statements by the Bundesbank president. Table 3 is consistent with the view that Schlesinger's statements were a wake-up call that changed investors' views of the prospects for central bank cooperation. While sterling had been in the news for weeks, pressure on the currency was still only moderate as measured by our EMP index. There was then relatively limited pressure on sterling (and for that matter on the French franc) on the first two days following the Italian realignment, but the pressure on sterling exploded with the publication of Schlesinger's interview.

Black Wednesday saw the Bank of England raise interest rates and expend $\$ 22.6$ billion in reserves, but also the Treasury suspend the country's membership in the ERM and allow the pound to depreciate. While intervention, the change in interest rates and the change in the exchange rate all contribute arithmetically to the high level of exchange market pressure recorded that day (the highest in our sample, some 35 standard deviations above the sample mean), the largest contributor is intervention. ${ }^{45}$ In part, this reflects a reluctance to raise interest rates (in

\footnotetext{
${ }^{45}$ Recall that what matters for our measure is not the absolute level of intervention but that level normalized by its standard deviation.
} 
contrast to other cases, such as that of the Swedish Riksbank, where there was no such reluctance, as noted above, and where interest rates contributed more, arithmetically, to our measure of exchange market pressure). The Bank of England announced two rate rises that day (and second of which was rescinded), but those increases were modest by the standards of other countries whose currencies were under pressure. ${ }^{46}$

In addition to Britain exiting the ERM, Italy announced to the Monetary Committee that evening that the inadequacy of its reserves forced it to float the lira. While the Portuguese escudo was defended, the Spanish peseta was devalued by 5 per cent. The contrast is striking, in that the pressure on the escudo was nearly four times as intense by our measure. Also noticeable is how pressure on sterling died down after Black Wednesday, when the currency was floated; evidently, market participants were confident that the Bank would develop a plan for managing inflation and the currency in the absence of an exchange rate anchor. (As it in fact did; that plan came to be known as inflation targeting.)

The French referendum on the Maastricht Treaty was still looming on September $20^{\text {th }}$. Our measure shows little pressure on the franc prior to Black Wednesday but sharp intensification thereafter. That the "oui" side squeaked to victory with a 51 per cent vote share was plausibly a factor in the continuing pressure on the franc, forcing the Bank of France to intervene to support the currency against the DM. Another spike was on September $22^{\text {nd }}$, when the Bank of France spent $\$ 10.9$ billion. After that, the franc recovered; Intervention fell to low levels, and the Bank of France was able to rebuild its reserves.

In November, Sweden finally abandoned its ecu peg, high interest rates having taken their toll. Spain devalued again, and this time Portugal followed. Sweden's troubles and generalized EMS turmoil also infected Norway. Our EMP index for Norway peaked on November $20^{\text {th }}$ at 26 standard deviations above the mean, the second highest value in the sample after the UK on Black Wednesday. The Norges Bank abandoned its ecu peg on December $10^{\text {th }}$. The Irish punt, which had come under pressure following Black Wednesday, was devalued by 10 per cent on January 30, 1993.

The Danish krone and Belgian franc also came under pressure in early 1993. Our indices do not indicate extensive intervention by either country's central bank. However, on February $3^{\text {rd }}, 1993$, the Netherlands Bank undertook $\$ 2.4$ billion of purchases to support the Danish krona, which had hit the lower band limit of its bilateral band. ${ }^{47}$ This is one of the negative spikes in the overall EMP index in Figure 4 above; it was a relatively rare instance of international cooperation. This finding supports the conclusion of Straumann (2010), who argues that support from other ERM countries helped Denmark stay in the ERM, unlike Sweden and Norway, which did not receive such support and had given up their pegs a few months earlier.

\footnotetext{
${ }^{46}$ Normally, a rate hike would have been announced at 9:45 in the morning; on 16 September the announcement was delayed until 11:00, indicative of internal debate. Household mortgages bore variable rates, and a higher Bank Rate meant pain for the Conservative Government's core constituency. (Recall that the Bank of England was not independent of the government at this time.) As one author has put it, "The economic distress of homeowners translated into political sustainability problems of the ERM peg for the ruling Conservative party, not least since the spread of homeownership was central to its project of socio-economic reform." Hassdorf (2007), p.144.

${ }^{47}$ In addition, there were purchases of $\$ 145$ million of Danish krone by the Bundesbank and $\$ 580$ million by the Central Bank of Ireland.
} 
The center of attention now was Iberia. The release in mid-February of disappointing Spanish unemployment figures for the fourth quarter of 1992 intensified selling pressure on the peseta, and elections on April 12 $2^{\text {th }}$ introduced further uncertainty about the intentions of the government. Reserve losses forced another 8 per cent devaluation on May $13^{\text {th }}$, and the spillover forced neighboring Portugal to devalue by an additional 6 1/2 per cent. Denmark then ratified the Maastricht Treaty in a second vote, and the Bundesbank lowered interest rates, partly to reduce pressure on other ERM countries. The French franc rallied in response, as French inflation showed signs of dropping below German inflation. The Bank of France responded by cutting interest rates in a bid to fight unemployment and in the hope of demonstrating its leadership of the EMS (in other words, in the hope Germany would follow its example).

These hopes were disappointed. French officials, led by Finance Minister Edmond Alphandéry, had been lobbying, via radio programs and in face-to-face meetings with their German counterparts, for interest rate cuts by the Bundesbank to relieve pressure on the franc and obviate the need for an uncomfortable increase in French interest rates. When it became known that French and German officials were unable to agree, pressure on the franc intensified. Table 4 suggest that as late as Wednesday July 28 this was a purely French phenomenon. The Bundesbank's failure to cut its discount rate on Thursday July 29 was then the final straw, and what had been a French crisis morphed into a European crisis. ${ }^{48}$ Figures from the Bundesbank's archives show that the German central bank spent approximately DM47 billion supporting the French franc on July $29-30{ }^{49}$

Table 4. Heat Map for July 1993 EMS Crisis

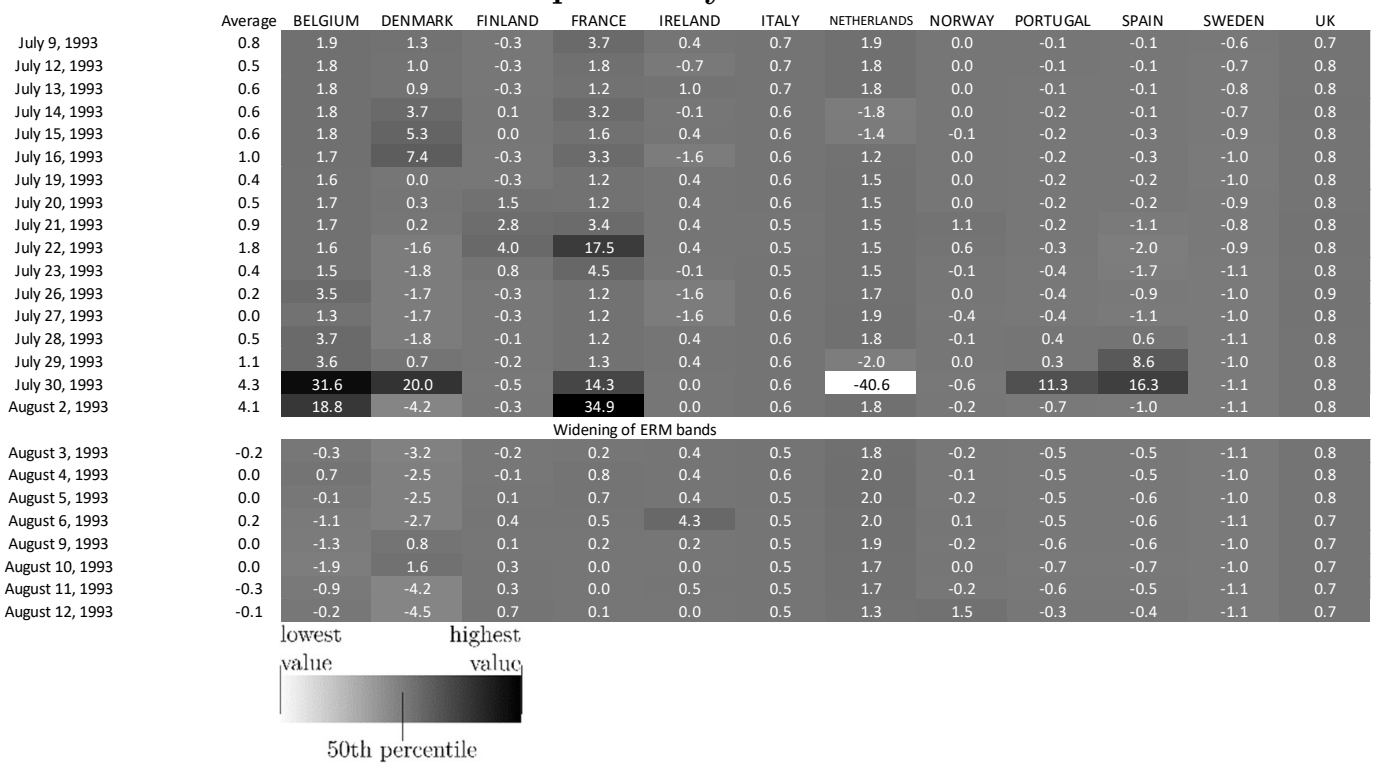

This got governments to the weekend. With little expectation that the pressure would subside, members agreed on August 2, 1993 to broaden their ERM bands from $2 \frac{1 / 4}{4}$ to 15 percent. The initial German proposal had been to broaden them to $+/-6$ per cent, the old wide bands operated

\footnotetext{
${ }^{48}$ The Bundesbank did cut the Lombard rate by 50 basis points, but this made little difference.

${ }^{49}$ DM47 billion on the two days combined. James reports large interventions by other central banks as well.
} 
by Italy, Spain and Portugal. Evidently the lesson had finally been learned that doing too little was even worse than doing nothing at all. France and others now insisted on more radical steps. ${ }^{52}$ Wider bands created more scope for exchange rates to move in both directions, creating twoway risk and discouraging investors from all lining up on one side of the market (Ayuso PerezJurado and Restoy 1994, Walsh 1995, Garretsen, Knot and Nijsse 1998). It gave European monetary policy makers a window of time in which to complete the transition to the single currency.

\section{The Role of the Dollar}

The literature on the crisis, summarized in Section 1, focuses on events in Europe, unsurprisingly since the crisis manifested itself in tensions between European currencies and changes in intraEuropean exchange rates. The prominent political events were European, such as the Danish and French referenda. The economic developments that attracted most attention, such as changes in German interest rates or Spanish unemployment, were similarly European. The crisis meetings were of European officials. Statements about the ERM were statements by European officials, while steps to calm the markets were by European central banks and governments. Thus, when blame for the crisis was apportioned, analysts pointed to economic imbalances in Europe (inadequate British competitiveness, excessive Italian deficits, Bundesbank interest rates that were excessive from the point of view of other European countries), European political events that raised or reduced the likelihood of eventually transitioning to a single currency, and limits to unlimited support. The analytical narrative of the preceding section reflects this emphasis.

What this misses is the role of the dollar. As far back as 1979, when the EMS was founded, commentators had observed that dollar depreciation created strains in the Exchange Rate Mechanism, insofar as flows out of the greenback went disproportionately into the DM, perennially the strong European currency (see for example Brown 1979 and James 2012). These issues arose again in the early 1990s. The U.S. had entered a recession in July 1990. ${ }^{53}$ Weak domestic demand dampened U.S. imports and created a need to switch U.S. production toward exports; these current account trends made for a weaker dollar (Figure 5). In addition, the onset of the recession led the Federal Reserve to cut interest rates (Figure 6). Funds consequently flowed out of U.S. fixed-income markets and into higher-yielding European assets, DM assets in particular. This tendency was reinforced by the fact that the Bundesbank was raising rates to counter the inflationary pressures created by German reunification and attendant deficit spending. The resulting shift in the capital account of the balance of payments meant additional downward pressure on the dollar. Reflecting these forces, the bilateral dollar/DM rate depreciated by nearly 20 per cent between its peak in July 1991 and trough in September 1992.

\footnotetext{
${ }^{52}$ The initial French proposal was for $+/-20$ per cent. +/-15 per cent was the eventual compromise.

${ }^{53}$ This is the date identified by the NBER Business Cycle Dating Committee.
} 
Figure 5. Dollar/DM exchange rate

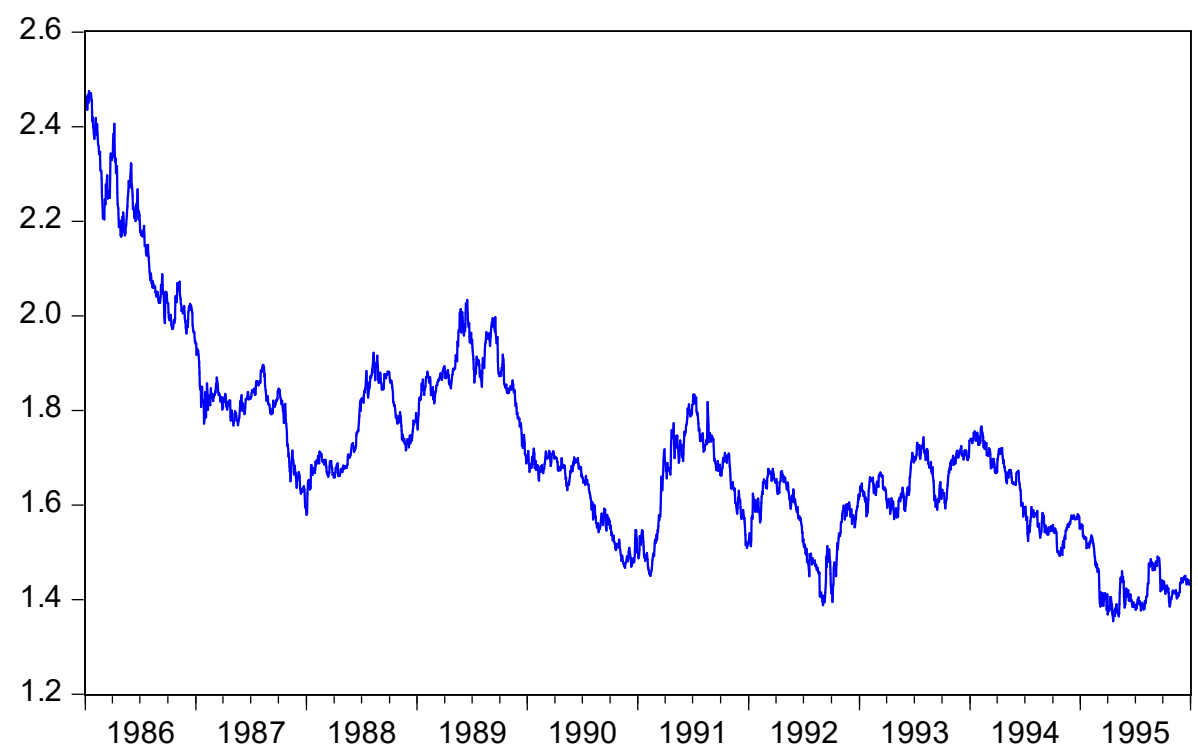

The time series for the dollar/DM exchange rate in Figure 5 is consistent with a role for the greenback in the crisis. Several major episodes of intra-ERM tension and not just that in 1992 are consistent with the hypothesis. The dollar had depreciated against the DM in the run-up to the 1987 general realignment, and it depreciated in the period leading up to the 1990 realignment of the lira. Figure 6 speaks less loudly for a role for the interest differential. No trend was evident in the period prior to the 1987 realignment, and the January 1990 realignment of the lira took place prior to recession-induced interest-rate cuts in the United States.

Movements in our exchange market pressure index are consistent with this emphasis on dollar depreciation. We showed above how EMP was rising already before the Danish referendum to which much attention is paid in conventional narratives. The dollar had begun depreciating earlier, already in the second half of 1991, and its depreciation continued through the first four months of 1992 (prior to the Danish referendum), consistent with this observation.

Contemporary reports noted the dollar's role. When the dollar hit a low against the DM at the outset of the September crisis, the Financial Times observed that "Traders reported widespread selling of dollars for D-Marks from international currency investors, particularly large fund management groups. Such investors have recently bought D-Marks in volume because of the big difference between German and US interest rates." ${ }^{54}$ In early September 1992 the dollar hit a record low. The FT noted that dollar depreciation was "depressing several of the weaker currencies against the D-Mark and pushing both sterling and the Italian lira closer to their ERM floors." ${ }^{55}$ Likewise, the Economist noted on August 29 that "[a]s investors rushed out of the American currency into D-marks, first sterling and then the lira were dragged down within Europe's exchange rate mechanism." ${ }^{156}$

\footnotetext{
${ }^{54}$ Financial Times, "Dollar Hits New Low against D-Mark", 2 September 1992, p.1.

${ }^{55}$ Financial Times, "Dollar Hits New Low against D-Mark", 2 September 1992, p.1.

${ }^{56}$ The Economist, "Forever falling?" 29 August 1992,Volume 324, Issue 7774.
} 
Figure 6. Fed funds rate and German official discount rate

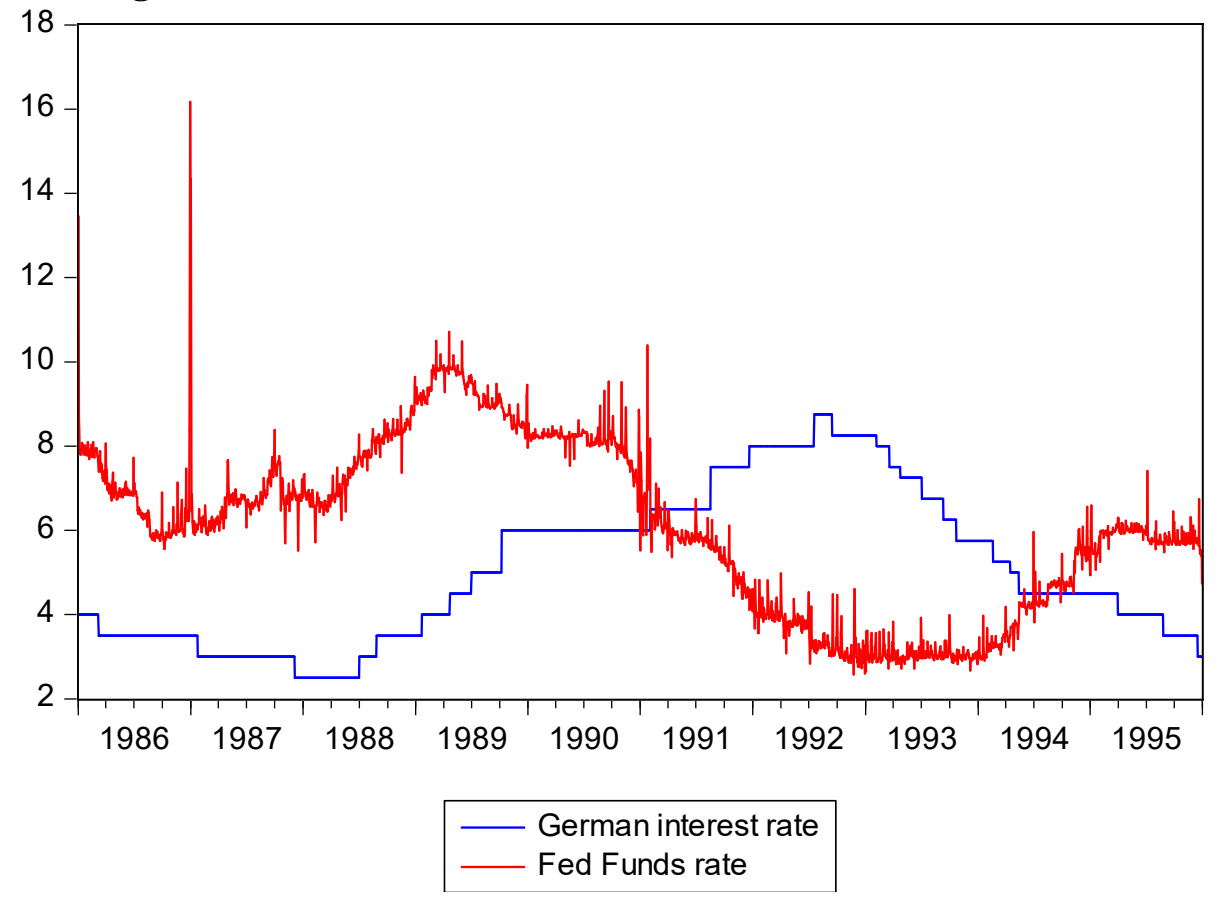

Policy makers similarly noted a role for the dollar. Meeting at the Bank for International Settlements on June 15, 1992, central bank governors complained that Italian measures to counter the pressure on the lira were "blunted by the weakening of the US dollar and the consequent strengthening of the Deutschmark." ${ }^{63}$ A month later, they were concerned that the "downward trend of the dollar was gaining momentum following the discount rate cut by the Federal Reserve in early July and the lack of supporting action from the G-7 countries." ${ }^{64}$ Bank of Italy Governor Ciampi argued that the explanation for the weak lira was to be found in the "market's intention of testing the strength of the Italian government, in the weakness of the US dollar and in the expectation that the Deutsche Bundesbank Council would raise German rates further." ${ }^{65}$

The Bundesbank was conscious of the strong dollar. It wrote in its annual report for 1992 how "lower interest rates in the United States induced a drop in the dollar which was an additional cause for tension" in the ERM. ${ }^{66}$ The OECD, in a November 1992 report, criticized the United States for "benign neglect" of the dollar exchange rate and observed that this fanned tensions within the EMS. ${ }^{67}$ The IMF, in its January 1993 "Interim Assessment of the World Economic

\footnotetext{
${ }^{63}$ Minutes of the 267th meeting of the Committee of Governors of the Central Banks of the Member States of the European Economic Community held in Basel on Monday, 15 the June 1992 at 9.00 am

${ }^{64}$ Minutes of the 268th meeting of the Committee of Governors of the Central Banks of the Member States of the European Economic Community, held in Basel on Tuesday, 14th July 1992 at 9.30 a.m.

${ }^{65}$ Minutes of the 268th meeting of the Committee of Governors of the Central Banks of the Member States of the European Economic Community, held in Basel on Tuesday, 14th July 1992 at 9.30 a.m.

${ }^{66}$ German original: "Die gleichzeitige zinsinduzierte Kursrückgang des US-Dollars wirkte als ein zusätzlischer Spannungsaulöser." 1992 Annual Report of the Bundesbank, 1 April 1993, p.81.

${ }^{67}$ Cited in Carl Gewitz, "ERM Works but System is Flawed, OECD Says," New York Times (9 November 1992), https://www.nytimes.com/1992/11/09/business/worldbusiness/IHT-erm-works-but-system-is-flawed-oecd-says.html
} 
Outlook," observed that intra-European exchange rate tensions were aggravated by "the weakness of the U.S. economy, the marked decline in U.S. interest rates, and the associated shift of funds into assets denominated in the strong European currencies, especially the deutsche mark." The BIS, in its 1992-3 annual report, published in August, concurred. "It is sometimes suggested that the weakness of the dollar during much of the spring and summer of last year was an important causal factor in the European crisis which followed. And it is certainly true that previous episodes of dollar weakness had been accompanied by strains in the ERM as capital flowed into the DM. In the present case it also seems likely that the unprecedented interest differential between the United States in Germany, with its attendant transatlantic exchange rate pressures, played at least a subsidiary role." ${ }^{168}$

Finally, the memos written by the Bank of England's foreign exchange dealers, drawn from the same archival source and covering the same period as the intervention data, are consistent with this focus on the DM and the dollar. These memos were written to describe market pressures and their sources for the benefit of Bank of England officials. ${ }^{69}$ A simple text analysis shows that the dealers mentioned "DM" on $32 \%$ of trading days and "dollar" on $29 \%$ of days. All other currencies are mentioned less than $1 \%$ of the time.

\section{Evidence on the Impact of the Dollar/DM Rate}

We now conduct a regression analysis, taking as dependent variables the number of central banks intervening, the value of their interventions, and exchange market pressure. We estimate ordinary least squares regressions and vector autoregressions. Both approaches point to the same conclusion

Our specification is of the form:

$$
Y_{t}=\beta_{0}+\beta_{1}\left(F x_{t-1}-F x_{t-2}\right)+\beta_{2} R_{t-1}^{G E R}+\beta_{3} X+\epsilon_{t}
$$

where $Y_{t}$ is one of the three dependent variable on day t: average EMP index for EMS countries ${ }^{70}$, number of EMS countries intervening and average DM intervention by EMS countries. $F x_{t-1}-$

\footnotetext{
${ }^{68}$ BIS (1993), pp.193-4. It then suggests that the resulting flows occurred in two stages, first from the dollar to highyielding European currencies and then, when stability worries arose, from those high-yielding currencies to the DM. "In addition, the prolonged easing of US monetary policy (before 1992), with its accompanying tendency to dollar weakness, had probably been one reason for capital to flow out of the dollar. Some of this outflow had no doubt gone into high-yielding European currencies and other assets denominated in the same currencies. In mid-1992, however, the situation suddenly reversed itself, and holders of high-yielding currencies were very quickly beginning to try to get out of them." BIS (1993), p.194.

${ }^{69}$ The memos have been digitized by Naef (2020b) and to read more about their context, see Naef (2019).

${ }^{70}$ Note that replacing the unweighted average EMP with an EMP weighted by the reserves of each country leads to somewhat smaller but still highly significant coefficients for the impact of the dollar/DM rate. The reduction in size is due to the more important role the UK plays in the weighted index, as a larger country with more reserves. At the same time, the UK is less affected by the dollar/DM rate. Additionally, the role of Ireland is reduced when country weights are used, and Ireland is affected relatively strongly by the dollar/DM rate. See the discussion of individual country responsiveness in Section 6 below.
} 
$F x_{t-2}$ is the lagged change in the exchange rate, $R_{t-1}^{G E R}$ is the lagged level of German interest rates, and $X$ are day of the week, month and year fixed effects. ${ }^{71}$ We lag the change in the exchange rate and the interest rate by one day to mitigate timing issues. ${ }^{72}$

Table 5. Impact of change in dollar/DM exchange rate and German interest rate

\begin{tabular}{|c|c|c|c|}
\hline & $\begin{array}{l}\text { Average } \\
\text { EMP for all } \\
\text { countries }\end{array}$ & $\begin{array}{l}\text { Number of } \\
\text { countries } \\
\text { intervening }\end{array}$ & $\begin{array}{l}\text { Average DM } \\
\text { intervention }\end{array}$ \\
\hline $\begin{array}{l}\text { Lagged change in exchange } \\
\text { rate }\end{array}$ & $\begin{array}{l}-4.69^{* * *} \\
(1.61)\end{array}$ & $\begin{array}{l}-1.63^{* * *} \\
(0.30)\end{array}$ & $\begin{array}{l}10640.11^{* * *} \\
(3419.70)\end{array}$ \\
\hline $\begin{array}{l}\text { Lagged German interest } \\
\text { rate }\end{array}$ & $\begin{array}{l}0.24^{* * *} \\
(0.03)\end{array}$ & $\begin{array}{l}0.04^{* * *} \\
0.006\end{array}$ & $\begin{array}{l}-87.70^{* *} \\
(44.24)\end{array}$ \\
\hline $\begin{array}{l}\text { Day, month and year } \\
\text { controls }\end{array}$ & yes & yes & yes \\
\hline $\mathrm{N}$ & 2342 & 2575 & 2575 \\
\hline R squared & 0.63 & 0.25 & 0.09 \\
\hline
\end{tabular}

In Table 5, all coefficients have their expected signs and differ significantly from zero. Dollar depreciation increases the pressure on ERM countries, is associated with additional central banks intervening, and raises the amount of intervention. (Note that our intervention variable registers a positive number when a central bank is buying DM - building up reserves - and negative when it is selling DM and intervening to defend its currency.)

Daily DM intervention rises by $\$ 11$ million per 10 daily basis point depreciation of the dollar. By comparison, total daily intervention over the 1986-1995 sample averaged \$66 million. It averaged $\$ 72$ million when we exclude days with zero intervention. The comparison suggests that even limited moves of the dollar/DM exchange rate could trigger interventions on the scale typical of the $1986-95$ period. $^{74}$

\footnotetext{
${ }^{71}$ The fixed effects are dummies for days of the week (Tuesday to Friday), month (January to December) and years (1986-1994). Most time fixed effects in our specifications are significant but they do not change the regressions in a significant way. They slightly increase $R$ squared and moderately affect the coefficients of interest.

${ }^{72}$ Since the exchange rate is a rate at the close, it is more likely to influence the pressure the following day. Interest rates in principle could influence both same-day and next-day pressure depending on when they are announced, but for consistency we use the previous day's rates. We return to this in the section on robustness.

${ }^{74}$ There were also atypical interventions, most obviously on Black Wednesday, when the value of intervention peaked at roughly $\$ 6$ billion on average for ERM countries. There being no corresponding 500 basis move in the dollar, this
} 
In addition, a higher German interest rate is associated with more exchange market pressure, more central banks intervening, and more extensive intervention.

Table 6. Impact of change in dollar/DM exchange rate and German interest rate

\begin{tabular}{llll}
\hline & $\begin{array}{l}\text { Average } \\
\text { EMP for } \\
\text { all } \\
\text { countries }\end{array}$ & $\begin{array}{l}\text { Number of } \\
\text { countries } \\
\text { intervening }\end{array}$ & $\begin{array}{l}\text { Average } \\
\text { DM } \\
\text { intervention }\end{array}$ \\
\hline Lagged change in exchange rate & $\begin{array}{l}-5.71^{* * *} \\
(1.68)\end{array}$ & $\begin{array}{l}-1.80^{* * *} \\
(0.32)\end{array}$ & $\begin{array}{l}11039.84^{* * *} \\
(3383.64)\end{array}$ \\
Lagged change in German interest & $0.40^{* * *}$ & 0.04 & $-304.35^{* *}$ \\
rate & $(0.11)$ & $(0.03)$ & $(127.09)$ \\
Day, month and year controls & & & \\
& yes & Yes & yes \\
\hline $\mathrm{N}$ & & & 2575 \\
$\mathrm{R}$ squared & 2342 & 2575 & 0.08 \\
\hline
\end{tabular}

Standard errors reported are estimated using heteroscedasticity and autocorrelation-consistent (HAC) estimators with a Newey-West correction. *** signifies statistically significant at the $1 \%$ level of significance; ${ }^{* *}$ at the $5 \%$ level of significance; ${ }^{*}$ at the $10 \%$ level of significance. We drop three outliers when intervention is above $\$ 15$ billion.

A potential concern is that the level of German interest rates is not stationary, since the Bundesbank had been raising its rate since 1988 and again following reunification, and then reducing it steadily starting in 1993 (Figure 6). This may introduce spurious correlation between the interest rate and the dependent variables and otherwise bias the coefficient estimates. In Table 6 we therefore substitute the lagged change in the interest rate, which is stationary. The results are the same, with the exception of a now insignificant coefficient on the number of countries intervening. ${ }^{75}$

Alternatively, we may wish to consider the interest rate differential between the U.S. and Germany, on the grounds that exchange market pressure is associated with the incentive for capital to flow from the U.S. to Germany, where that flow is accentuated by a larger difference between U.S. and German interest rates. ${ }^{76}$ The signs of all coefficients again remain the same. While the effect of interest rates on exchange market pressure and the amount of intervention is no longer significant, the coefficients on our variable of interest, namely the lagged change in the dollar/DM exchange rate, remain significantly different from zero at high levels of confidence.

points to the possibility of nonlinearities - which is of course precisely what models of speculative attacks on currency pegs would lead one to expect.

${ }^{75}$ Lower levels of significance reflect the fact that there were only a limited number (35) changes in the Bundesbank's rate over the period.

${ }^{76}$ This lagged interest differential is stationary as well. 
Table 7. Impact of change in dollar/DM exchange rate and interest differential

\begin{tabular}{llll} 
& $\begin{array}{l}\text { Average } \\
\text { EMP for } \\
\text { all } \\
\text { countries }\end{array}$ & $\begin{array}{l}\text { Number of } \\
\text { countries } \\
\text { intervening }\end{array}$ & $\begin{array}{l}\text { Average DM } \\
\text { intervention }\end{array}$ \\
\hline Lagged change in exchange rate & $\begin{array}{l}-5.71^{* * *} \\
(1.67)\end{array}$ & $\begin{array}{l}-1.82^{* * *} \\
(0.32)\end{array}$ & $\begin{array}{l}11028.37^{* * *} \\
(3386.54)\end{array}$ \\
Lagged interest differential & 0.004 & $0.009^{*}$ & -61.67 \\
(Germany-US) & $(0.04)$ & $(0.005)$ & $(50.10)$ \\
& & & Yes \\
Day, month and year controls & Yes & Yes & 2571 \\
& & & 0.08 \\
\hline N squared & 2339 & 2571 & 0.22 \\
\hline
\end{tabular}

Standard errors reported are estimated using heteroscedasticity and autocorrelation-consistent (HAC) estimators with a Newey-West correction. *** signifies statistically significant at the $1 \%$ level of significance; ** at the $5 \%$ level of significance; * at the $10 \%$ level of significance. We drop three outliers when intervention is above $\$ 15$ billion.

If the interest rate variables in Tables 5 and 6 are picking up capital flows between Germany and other ERM countries, and if those in Table 7 pick up the incentive for capital movements between Germany and the U.S., then there is a logic for including both. We do so in Table 8. Again nothing changes. The lagged level of German interest rates increases exchange market pressure, intervention, and the number of intervening central banks. The Germany-US interest differential significantly increases only the number of countries intervening, as before. ${ }^{78}$ Most importantly, the coefficients on the variable of interest, the lagged change in the exchange rate, retain their previous sign and significance. Across all these tables, their magnitudes are little changed.

We can use the estimates in Table 8 to compare the quantitative impact of dollar/DM exchange rate changes, as emphasized in this paper, with changes in German monetary policy, as emphasized in previous literature. For example, depreciation from $\$ 1.6$ to $\$ 1.4 \mathrm{DM}$ per dollar, a not atypical move in the period under study (reference Figure 5 above), has four times the impact on exchange market pressure as a 100 basis point increase in the Bundesbank policy rate. These exchange-rate effects are large and economically consequential. This highlights the economic importance of the neglected channel we emphasize here.

\footnotetext{
${ }^{78}$ Its coefficient in the EMP equation switches sign relative to Table 11, but was insignificant there and is insignificant here.
} 
Table 8. Impact of change in dollar/DM exchange rate, German rate and interest differential

\begin{tabular}{|c|c|c|c|}
\hline & $\begin{array}{l}\text { Average } \\
\text { EMP for } \\
\text { all } \\
\text { countries }\end{array}$ & $\begin{array}{l}\text { Number of } \\
\text { countries } \\
\text { intervening }\end{array}$ & $\begin{array}{l}\text { Average } \\
\text { DM } \\
\text { intervention }\end{array}$ \\
\hline Lagged change in exchange rate & $\begin{array}{l}-4.71^{* * *} \\
(1.60)\end{array}$ & $\begin{array}{l}-1.64^{* * *} \\
(0.30)\end{array}$ & $\begin{array}{l}10636.13^{* * *} \\
(3421.92)\end{array}$ \\
\hline Lagged German interest rate & $\begin{array}{l}0.23^{* * *} \\
(0.03)\end{array}$ & $\begin{array}{l}0.04^{* * *} \\
(0.006)\end{array}$ & $\begin{array}{l}-88.14^{* *} \\
(44.30)\end{array}$ \\
\hline $\begin{array}{l}\text { Lagged interest rate differential } \\
\text { (Germany-US) }\end{array}$ & $\begin{array}{l}-0.002 \\
(0.04)\end{array}$ & $\begin{array}{l}0.009^{*} \\
(0.005)\end{array}$ & $\begin{array}{l}-61.23 \\
(50.12)\end{array}$ \\
\hline Day, month and year controls & Yes & Yes & Yes \\
\hline $\mathrm{N}$ & 2339 & 2571 & 2571 \\
\hline $\mathrm{R}$ squared & 0.63 & 0.26 & 0.09 \\
\hline
\end{tabular}

\section{Robustness}

Additional robustness checks confirm these findings. ${ }^{80}$ We substituted the change in the sameday exchange rate for the lagged exchange rate, with no impact on the results. We dropped the lagged interest differential and the day, month and year controls, again replicating our result for the dollar/DM rate. The significance of the coefficients on the change in the exchange rate is not sensitive to the inclusion or exclusion of the interest rate variable.

Subdividing the sample again produces consistent results. Focusing exclusively on the crisis period from June 1992 through July 1993 produces similar results, although standard errors are larger, reflecting the smaller sample size. Interacting the change in the dollar/DM exchange rate with a dummy variable for whether the dollar was appreciating or depreciating on the day in question indicates that the contribution of the dollar/DM rate was larger and more significant on days when the dollar was depreciating, consistent with contemporary concerns. Similarly, dividing the sample into subperiods when the dollar was depreciating (appreciating) on trend

${ }^{80}$ These additional results are reported in Appendix D. 
again produces consistent results, while showing that changes in the dollar/DM rate contribute more to exchange market pressure in periods of trend depreciation, consistent with contemporary commentary (viz. Section 3 above). Estimating Markov regime-switching regressions produced even stronger effects of the dollar/DM rate on the exchange-market pressure on European countries. Our Markov regime-switching regressions identify two regimes, one centered on days around successive peaks of the ERM crisis in September 1992 and July 1993, and another covering non-crisis periods. During the crisis regime, the effect of a falling dollar against the DM is larger and differs from zero at even higher confidence levels than in the non-crisis regime.

To confirm that there is a persistent impact of changes in the dollar/DM rate as opposed to just transient pressure, we replicated the analysis using monthly average data. The results are again the same.

We found similar results when we estimated the same relationships for individual countries as opposed to averaging EMP across European countries. Italy sees the greatest intensification of EMP in response to a fall in the dollar against the DM, in line with the narrative in Section $4 .{ }^{81}$ All other countries similarly show an increase in EMP in response a fall in the dollar, with the sole exception of the UK.

These country-specific results also enable us to implement insights from the literature on exchange rate target zones (Krugman 1991). The central insight runs as follows. If a target zone is credible (if a central bank is expected to take offsetting intervention as the edge of the band or zone is approached), then market participants will buy or sell the currency in anticipation of that intervention. This will prevent the currency from breaching the band; exchange market pressure will be reduced. In contrast, if the target zone is not credible, then market participants will transact in the other direction, and pressure will intensify as the edge of the band is approached (Bertola and Caballero 1992).

We therefore constructed a variable measuring how close each currency was to the edge of its +/- $21 / 4$ or 6 percent band and interacted this with our key determinant of EMP, namely the dollar/DM rate. If the band is credible, then the impact of that variable will be smaller as the edge of the band is approached (the sign of the interaction term will be the opposite of the sign on the dollar/DM rate itself. The converse will be true if the band is not credible and a country's central bank is expected to realign or exit the ERM when tested.

For Spain and Ireland, the coefficient on the interaction term has the same sign as that on the dollar/DM rate and differs significantly from zero at standard confidence levels. These estimates thus point to market expectations of realignment or ERM exit for two countries that did in fact realign in 1992-3.

We again found similar results when we varied the weights on the three components of the EMP index. Our baseline EMP measure places a much heavier weight on the change in exchange rate than intervention. This is consistent with the observation that intervention is likely to have only

${ }^{81}$ It is followed by Ireland and Norway. 
a limited impact on the foreign exchange market in advanced countries, given the relatively high substitutability of domestic- and foreign-currency-denominated assets (Goldberg and Krogstrup 2018). Girton and Roper (1977), in contrast, place equal weights on the components of their index. When we substitute Girton and Roper weights, we again obtain very similar results. ${ }^{82} \mathrm{We}$ again find similar results when we use relative weights on the change in the exchange rate and foreign exchange market intervention in the range bounded between our baseline weights and Girton and Roper's equal weights. ${ }^{83}$

\section{Figure 7. Impulse response to changes in dollar/DM exchange rate and German interest rate}

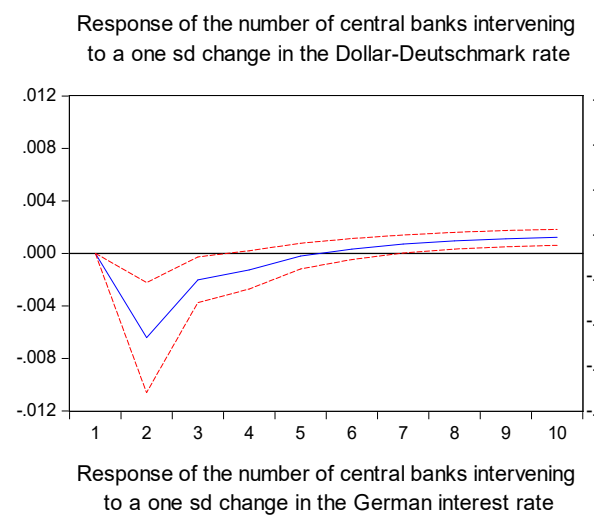

Response of the EMP to a one sd change in the Dollar-Deutschmark rate

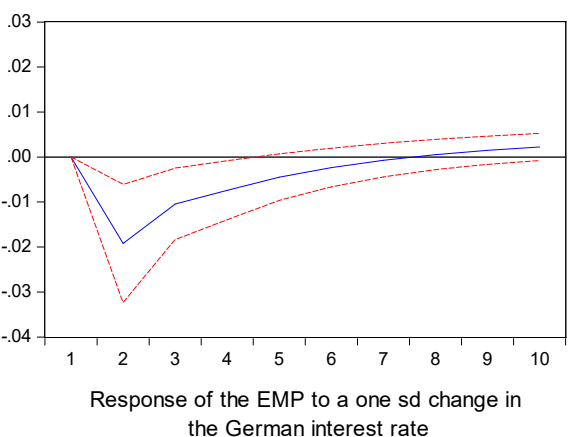
the German interest rate

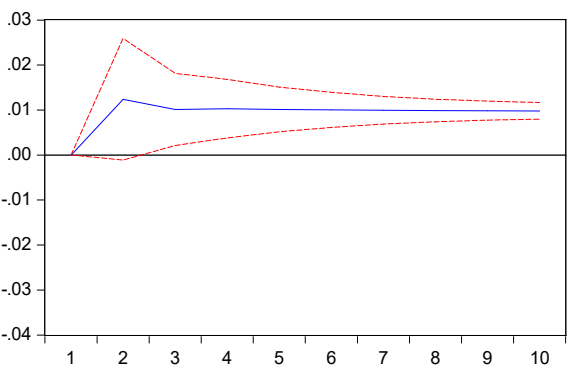

Response of the total intervention amount to a one sd change in the Dollar-Deutschmark rate

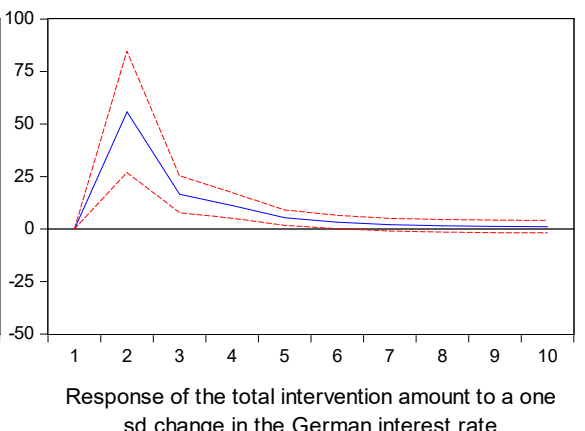

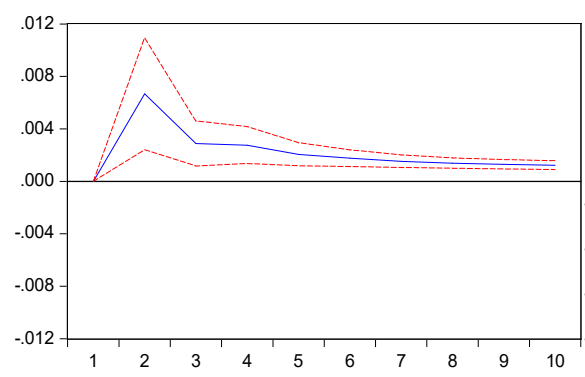

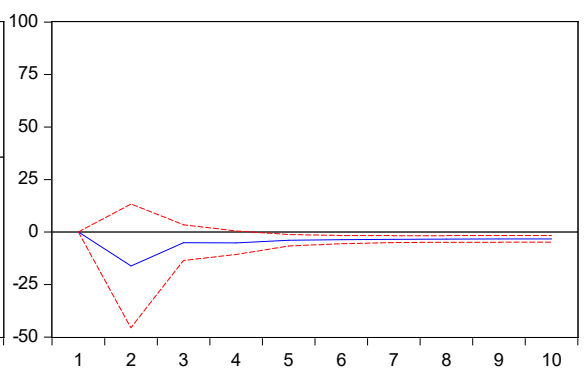

Response to cholesky one standard innovations. The dashed lines represent \pm 2 standard errors.

Replicating the analysis in a vector autoregression (VAR) setting further establishes robustness. The variables again are the dollar/DM rate, the German interest rate, EMP, the number of

\footnotetext{
${ }^{82}$ We are not able to implement Goldberg and Krogstrup's approach. Balance-of-payments data used in their exercise is missing for some countries for our earlier period. Goldberg and Kreogstrup also derive some monthly series used in their analysis by interpolating quarter and annual data. Interpolating daily observations from quarterly and annual data would not make sense. In addition, some of the parameters used to calibrate their model (the response of asset stocks to changes in exchange rates and interest rates, for example) were estimated on quarterly data. We would need the equivalent daily elasticities - which haven't been estimated because day over day changes in the relevant asset stocks do not exist. Goldberg and Krogstrup note that their indices for advanced countries place a relatively light weight on intervention, since the latter has a limited impact on the foreign exchange market, given the high substitutability of domestic- and foreign-currency-denominated assets. This suggests that results using their approach would more closely resemble those using our baseline weights rather than Girton and Roper's weights.

${ }^{83}$ We cannot implement Goldberg and Krostrup's (2018) model-based approach to deriving weights because we lack relevant balance of payment data for some countries for our earlier period.
} 
intervening central banks and intervention amounts. ${ }^{85}$ We include two lags, maximizing the log likelihood. We remove Black Wednesday because this massive outlier greatly impacts the estimates.

Figure 7 shows the impulse response to an increase in the dollar/DM rate and, alternatively, to the German interest rate. The results are again the same as in Tables 5-8. Dollar appreciation leads to less pressure, fewer countries intervening, and central banks accumulating reserves (positive intervention indicates reserve accumulation). Conversely, an increase in the German interest rate (bottom panel of Figure 7) leads to more pressure, more countries intervening, and more total intervention in defense of European currencies (though this last effect is significant only after the first five days).

Table 9. Value of R-squared in counterfactual analysis

\begin{tabular}{llll}
\hline & $\begin{array}{l}\text { Average } \\
\text { EMP for all } \\
\text { countries }(\mathrm{r}- \\
\text { squared) }\end{array}$ & $\begin{array}{l}\text { Number of } \\
\text { countries } \\
\text { intervening } \\
\text { (r-squared) }\end{array}$ & $\begin{array}{l}\text { Average DM } \\
\text { intervention } \\
\text { (r-squared) }\end{array}$ \\
\hline $\begin{array}{l}\text { Dollar-DM rate } \\
\text { (benchmark from Table 8) }\end{array}$ & 0.63 & 0.25 & 0.09 \\
\hline Dollar-Dutch guilder rate & 0.61 & 0.24 & 0.08 \\
Dollar-French franc rate & 0.60 & 0.23 & 0.08 \\
Dollar-Belgian franc & 0.60 & 0.21 & 0.08 \\
Dollar-Norwegian krone & 0.60 & 0.21 & 0.07 \\
Dollar-Italian lira rate & 0.59 & 0.20 & 0.07 \\
Dollar-Spanish pesetas & 0.58 & 0.21 & 0.08 \\
Dollar-British pound & 0.58 & 0.20 & 0.07 \\
\hline So
\end{tabular}

Source: see text.

We also undertook the same analysis instead using Jorda (2005) local projections. 5 of 6 estimates projecting the response of EMP, number of intervening banks and value of intervention to, alternatively, the dollar/DM rate and the German interest rate show the same initial response as the VARs. ${ }^{86}$ The effect after 3-4 days is noisier since, as Barnichon and Brownlees (2019) show, local projections can generate excessive volatility after the initial periods. Standard errors for the local projection indicate that not all these results are statistically significant.

Finally, we conducted a counterfactual analysis. Although the immediately preceding analysis suggests that the dollar/DM rate was an important factor contributing to the pressure on

${ }^{85}$ Our baseline analysis dropped the day, week and month, controls, since including them is likely to bias the VAR. Including them yields very similar results.

${ }^{86}$ Appendix E shows the results. 
European currencies, it is at least conceivable that some of the variation we capture is due to movements in the dollar, independently of the DM. For example, the dollar/DM rate and the dollar/French franc rate tend to be positively correlated. If dollar depreciation against the franc, and not only dollar depreciation against the DM, intensifies the pressure on other EMS currencies but we include in our model only the dollar/DM rate, then there is a risk of attributing to the dollar/DM rate the effects of other bilateral dollar rates.

To explore this, we replace the German exchange and interest rate with their other European counterparts. Table 9 reports the $\mathrm{R}$ squared for each model. The results confirm that pressure on ERM currencies is best explained by German exchange rates and interest rates, consistent with the dollar/DM hypothesis that the DM is a closer substitute for the dollar than are other European countries. The explanatory power of the Dutch guilder comes closest, not surprisingly since the guilder was widely regarded by market participants as a proxy for the German currency. Peripheral European currencies do a poorer job of explaining the pressure on European countries, as expected.

Overall, this is evidence that the dollar played an important role in the development of exchange market pressure in Europe in this period.

\section{Conclusion}

Using new data on foreign exchange market intervention, we have provided a fresh perspective on the 1992-3 EMS crisis. We use those data, together with exchange rates and interest rates, to construct a daily measure of exchange market pressure. The resulting series allows us to pinpoint when and where the 1992-3 crisis was most intense. It shows that pressure on EMS currencies started building well before the Danish referendum. It points to a fateful interview by Bundesbank President Schlesinger prior to the September 1992 French referendum on the Maastricht Treaty as the event triggering the most acute phase of the crisis.

The new data also enable us to revisit the role of the dollar. Relating the time-series for exchange market pressure to changes in the dollar/DM exchange rate and in U.S. German interest differentials, we confirm that dollar depreciation in 1991-2 was a major factor in the crisis.

Contemporaries drew several lessons from the 1992-3 episode. They concluded that divergences and imbalances between EMS member states could generate intense pressure on ERM parities. They saw that large cross-border financial flows in an environment free of capital controls could produce self-fulfilling prophecies, in which doubts about the stability of a currency could lead to the very instability anticipated by market participants. Both conclusions - that convergence should proceed more rapidly and that the ESM was intrinsically fragile - provided motivation for completing the Maastricht process culminating in monetary unification.

But so too did a third lesson, that the system could be upended by disturbances from outside, specifically exchange rate shocks coming from the United States. Only completing the transition to the euro could insulate intra-European exchange rates from this threat. Although subsequent 
historical accounts and economic analyses generally neglected this problem, contemporaries were aware and concerned about it. The analysis here indicates that they were right to be concerned.

\section{References}

Abdelal, Rawi. 1998. "The Politics of Monetary Leadership and Followership: Stability in the European Monetary System since the Currency Crisis of 1992." Political Studies XLVI: 236-259.

Ayuso, Juan, Maria Perez-Jurado and Fernando Restoy. 1994. "Is Exchange Rate Risk Higher in the ERM after the Widening of Fluctuation Bands?" unpublished manuscript, Bank of Spain.

Bai, Jushan, and Pierre Perron. 2003. "Critical Values for Multiple Structural Change Tests." Econometrics Journal 6: 72-78.

Barnichon, Regis, and Christian Brownlees. 2019. "Impulse Response Estimation by Smooth Local Projections." The Review of Economics and Statistics 101: 522-30.

Berdahl, Robert 2005. "German Reunification in Historical Perspective," Berkeley Journal of International Law 496: 496-505.

Bertola, Guiseppe and Ricardo Caballero 1992. "Target Zones and Realignments," American Economic Review 82: 520-536.

Bordo, Michael D., Owen F. Humpage, and Anna J. Schwartz. 2015. Strained Relations: US Foreign-Exchange Operations and Monetary Policy in the Twentieth Century. Chicago: University of Chicago Press.

Brander, Peter, Harald Grech and Helmut Stix 2006. "The Effectiveness of Central Bank Intervention in the EMS: The Post-1993 Experience," Journal of International Money and Finance 25: 580-597.

Branson, William. 1993. "Comment on 'The Unstable EMS'." Brookings Papers on Economic Activity 1: 125-129.

Brown, Brendan 1979. The Dollar/Mark Axis, London: Macmillan.

Bubow, Jörg 2013. "On the Franco-German Euro Contradiction and Ultimate Euro Battleground," Levy Economics Institute Working Paper no.762 (April).

Buiter, Willem H., Giancarlo Corsetti, and Paolo A. Pesenti. 2001. Financial Markets and European Monetary Cooperation: The Lessons of the 1992-93 Exchange Rate Mechanism Crisis. New York: Cambridge University Press.

Davies, Hannah Catherine. 2018. Transatlantic Speculations: Globalization and the Panics of 1873. New York: Columbia University Press.

Dyson, Kenneth and Kevin Featherstone 1999. The Road to Maastricht: Negotiating Economic and Monetary Union: Oxford: Oxford University Press. 
ECLAC. 1996. The Economic Experience of the Last Fifteen Years: Latin America and the Caribbean 1980-1995. Santiago: ECLAC.

Edison, Hali and Linda Kole. 1995. "European Monetary Arrangements: Implications for the Dollar, Exchange Rate Variability and Credibility." European Financial Management 1: $61-86$.

Eichengreen, Barry. 2002. "The EMS Crisis in Retrospect." in Bank of Mexico ed., Stabilization and Monetary Policy: The International Experience. Mexico City: Bank of Mexico.

Eichengreen, Barry. 2020. "A Hundred Years of the Modern Foreign Exchange Market in London," unpublished manuscript, University of California, Berkeley (March).

Eichengreen, Barry, Andrew Rose and Charles Wyplosz. 1995. "Exchange Market Mayhem: The Antecedents and Aftermath of Speculative Attacks." Economic Policy 10: 249-312.

Eichengreen, Barry, and Charles Wyplosz. 1993. "The Unstable EMS." Brookings Papers on Economic Activity 1: 51-143.

Forder, James and Stan Hurn. 2003. "Dollar-Deutschemark Polarisation: Comparing the Pound and Franc." Scottish Journal of Political Economy 50: 217-231

Froot, Kenneth A., and Maurice Obstfeld. 1991. "Exchange-Rate Dynamics under Stochastic Regime Shifts: A Unified Approach." Journal of International Economics 3: 203-229.

Giavazzi, Francesco and Alberto Giovannini. 1989. Limiting Exchange Rate Variability: The European Monetary System. Cambridge, Mass.: MIT Press.

Giovannini, Alberto. 1989. "How Do Fixed-Exchange-Rate Regimes Work: Evidence from the Gold Standard, Bretton Woods and the EMS." In Marcus Miller, Barry Eichengreen and Richard Portes eds., Blueprints for Exchange Rate Management. New York: Academic Press: $13-41$.

Girton, Lance, and Don Roper. 1977. "A Monetary Model of Exchange Market Pressure Applied to the Postwar Canadian Experience." American Economic Review 67: 537-48.

Goldberg, Linda S., and Signe Krogstrup. 2018. "International Capital Flow Pressures." NBER Working Paper No. 24286 (March).

Gros, Daniel 2014. "The EMS Crisis of the 1990s: Parallels with the Present Crisis," CEPS Working Document no.393 (March).

Gros, Daniel and Niels Thygesen. 1992, European Monetary Integration, London: Longman.

Habib, Maurizio and Livio Stracca. 2011. "Getting Beyond Carry Trade: What Makes a Safe Haven Currency?" ECB Working Paper no.1288 (January).

Haldane, Andrew and Stephen Hall. 1991. "Sterling's Relationship with the Dollar and the Deutschmark: 1976-89," Economic Journal 101: 436-443.

Harmon, Mark and Dorothy Heisenberg. 1993. "Explaining the European Currency Crisis of September 1992." German Politics \& Society 29: 19-51. 
Hassdorf, Wolf. 2007. "Contested Credibility; the Use of Symbolic Power in British ExchangeRate Politics," in Felix Berenskoetter and J.J. Williams eds, Power in World Politics, London: Routledge, pp.141-161.

Honkapohja, Seppo and Erkki Koskela. 1999. "The Economic Crisis of the 1990s in Finland," Economic Policy 14: 399-436.

James, Harold. 2012. Making the European Monetary Union, Cambridge, Mass.: Belknap Press of Harvard University Press.

James, Harold 2020. Making a Modern Central Bank: The Bank of England 1979-2003. Cambridge: Cambridge University Press.

Jorda, Oscar. 2005. "Estimation and Inference of Impulse Responses by Local Projections." American Economic Review 95: 161-182.

Kaminsky, Graciela and Carmen Reinhart. 2000. "On Crises, Contagion and Confusion," Journal of International Economics 51: 145-168.

Krugman, Paul. 1991. "Target Zones and Exchange Rate Dynamics," Quarterly Journal of Economics 106: 669-682.

Lewis-Beck, Michael and Daniel Morey. 2007. "The French 'Petit Oui': The Maastricht Treaty and the French Voting Agenda," Journal of Interdisciplinary History 38: 65-87.

Mee, Simon 2019. Central Bank Independence and the Legacy of the German Past. Cambridge: Cambridge University Press.

Mitchener, Kris and Marc Weidenmier. 2008. "The Baring Crisis and the Great Latin American Meltdown of the 1890s." Journal of Economic History 68: 462-500.

Naef, Alain. 2019. Sterling and the Stability of the International Monetary System, 1944-1971. Ph.D. dissertation, University of Cambridge. https://doi.org/10.17863/CAM.32540.

Naef, Alain. 2020a. "Dirty Float or Clean Intervention? The Bank of England in the Foreign Exchange Market." European Review of Economic History 25: 180-201.

Naef, Alain. 2020b. "Blowing against the Wind? A Narrative Approach to Central Bank Foreign Exchange Intervention." Working Paper 0188. European Historical Economics Society (June).

Pesenti, Paolo and Cedric Tille. 2000. "The Economics of Currency Crises and Contagion: An Introduction." Federal Reserve Bank of New York Economic Policy Review (September): $3-16$.

Sauga, Michael, Stefan Simons and Klaus Wiegrefe. 2010. "Was the Deutsche Mark Sacrificed for Reunification?" Spiegel Online (30 September).

Tietmeyer, Hans 1998. "Financial Crisis Management in the EU/ERM," in Scheherazade Rehman (ed), Financial Crisis Management in Regional Blocs, Boston: Kluwer Academic Publishers, pp.39-54. 
Truman, Edwin 2002. "Economic Policy and Exchange Rate Regimes: What Have We Learned in the Ten Years since Black Wednesday?" Speech at the European Monetary Symposium, London School of Economics, London, England https://www.piie.com/commentary/speeches-papers/economic-policy-and-exchangerate-regimes-what-have-we-learned-ten-years

Walsh, Brendon. 1995. "The Effects of the Widening of the ERM Bands on the Irish Pound." Working Paper no.1995.05, School of Economics, University College Dublin. 


\section{Appendix A: Data Sources}

\section{Daily intervention data}

Archives of the Bank of England, Dealers' daily reports, reference C8.

Archives of the Deutsche Bundesbank, Daily market reports, Hauptabteilung Ausland, reference B330_3184, 41585, 32834 for (7/29/1993 to 4/8/1993 only).

\section{Exchange rates}

Mostly from Global Financial Data. Rates for the Greek Drachma are cross rates obtained using the DEM/USD rate. Rebecca Stuart for pointing us to the Irish punt exchange rates (https://www.centralbank.ie/docs/default-source/statistics/interest-rates-exchange-rates/exchangerates/ieprates-1979-1988.xls?sfvrsn=6), for which we are grateful.

\section{Interest rate data}

Belgium: We are grateful to Pierre Wunsch, Hugues Fameree and Raf Wouters for sharing the data with us.

Denmark: BIS (2019) 'Central Bank Policy Rates' Available online: https://www.bis.org/statistics/cbpol.htm?m=6\%7C382\%7C679 Accessed: 5 May 2019.

Finland: We are grateful to Juha Tarkka for sharing data with us.

France: We are grateful to Vincent Bignon for sharing data with us.

Germany: Center for Financial Stability (2019), "Historical financial statistics,"' available at http://www.centerforfinancialstability.org/hfs.php Accessed: 5 May 2019.

Ireland: We thank Rebecca Stuart at the Bank of Ireland for sharing rates with us.

Italy: Center for Financial Stability (2019), "Historical financial statistics," available at http://www.centerforfinancialstability.org/hfs.php Accessed: 5 May 2019.

Norway: We are grateful to Oyvind Ethrheim for pointing us to Norwegian rates (https://www.norges-bank.no/en/topics/Monetary-policy/Policy-rate/Key-policy-rate-Monetarypolicy-meetings-and-changes-in-the-policy-rate/) Accessed: 28 June 2019.

Portugal: We thank Jorge Braga de Macedo and Luis Catela Nunes with help with data. Partial data are at https://www.bportugal.pt/EstatisticasWeb/(S(j34c2e23dz2x4045jdu2q045))/DEFAULT.ASPX?La ng=en-GB Accessed: 19 August 2019.

Spain: Banco de Espana, Boletin Estadistica. 2019. "Monthly Policy Rate," available at https://www.bde.es/webbde/en/estadis/infoest/tipos/tipos.html Accessed: 5 May 2019.

Sweden: BIS. 2019. "Central Bank Policy Rates," available at https://www.bis.org/statistics/cbpol.htm?m=6\%7C382\%7C679 Accessed: 5 May 2019.

UK: Bank of England. 2019. "Bank Policy Rate," available at https://www.bankofengland.co.uk/monetary-policy/the-interest-rate-bank-rate Accessed: 5 May 2019.

US: FRED. "Effective Federal Funds Rate," available at https://fred.stlouisfed.org/series/FEDFUNDS Accessed: 5 May 2019. 


\section{Appendix B: Individual Country EMP Indices}

Figure B1. EMP index for Belgium

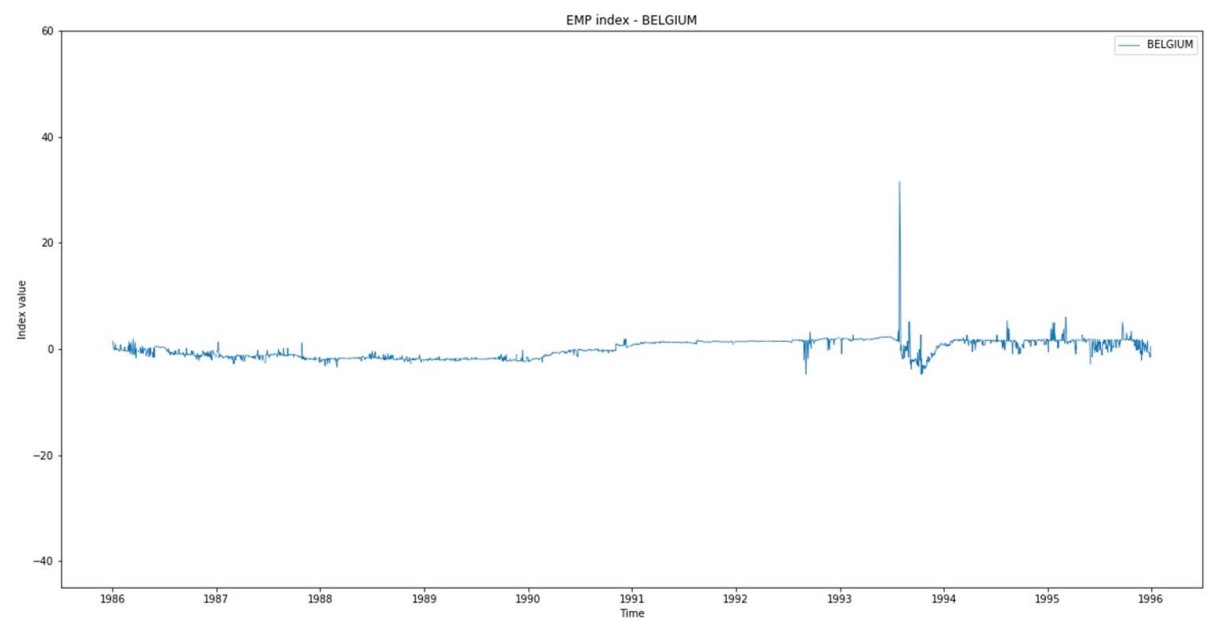

Figure B2. EMP index for Denmark

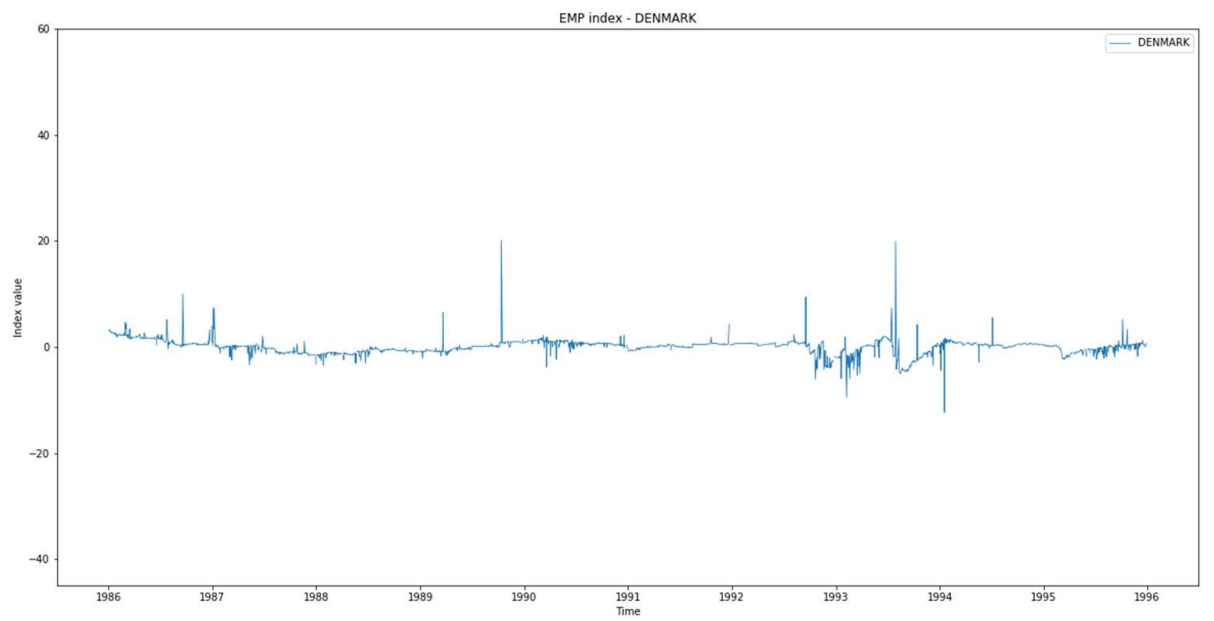


Figure B3. EMP index for Finland

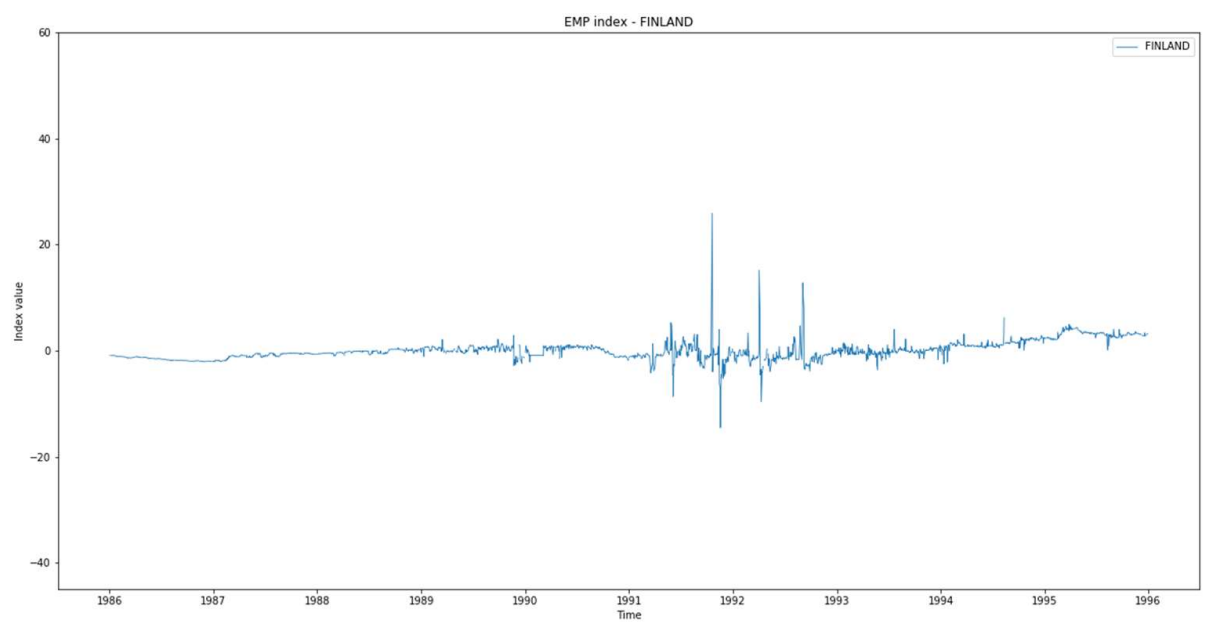

Figure B4. EMP index for France

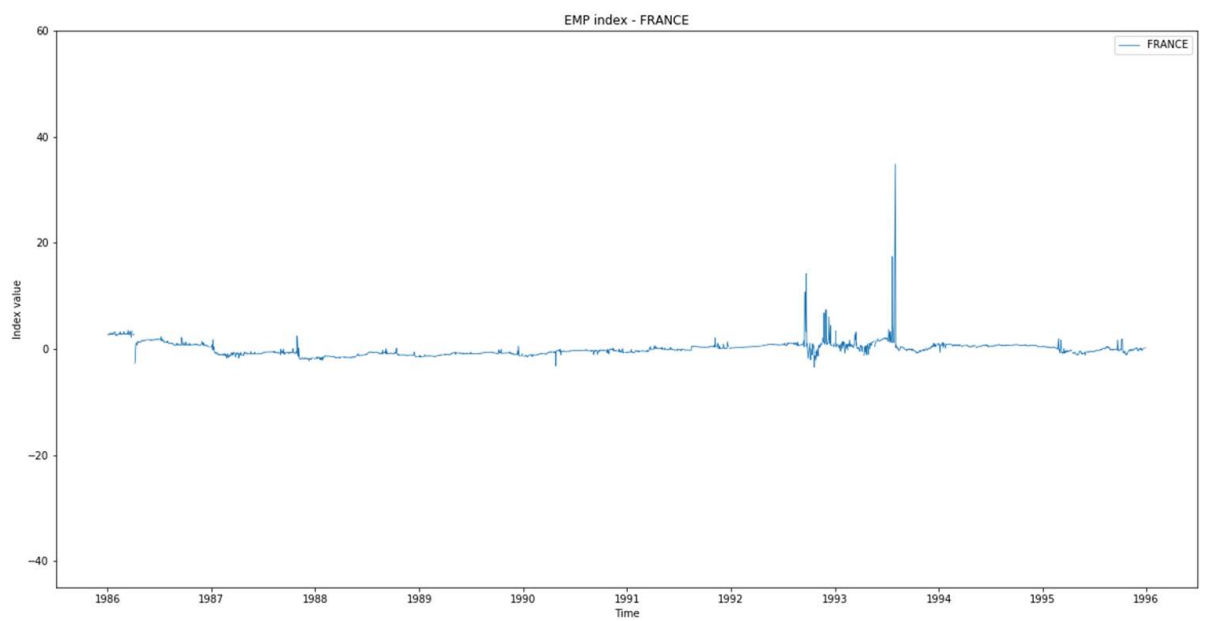


Figure B5. EMP index for Italy

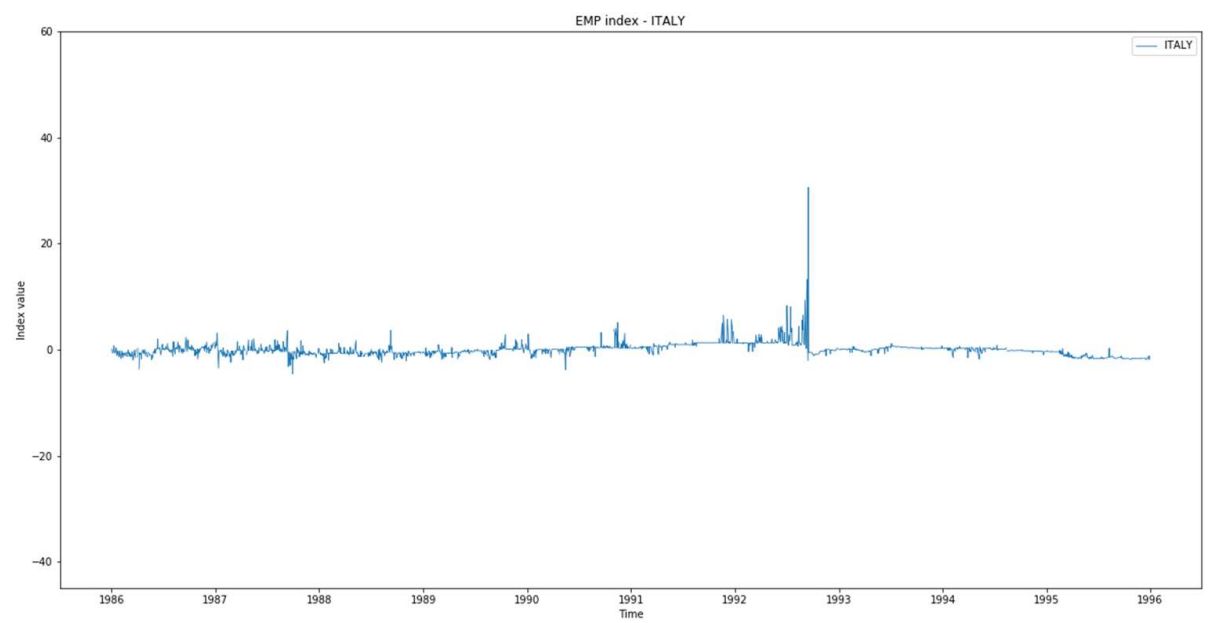

Figure B6. EMP index for Ireland

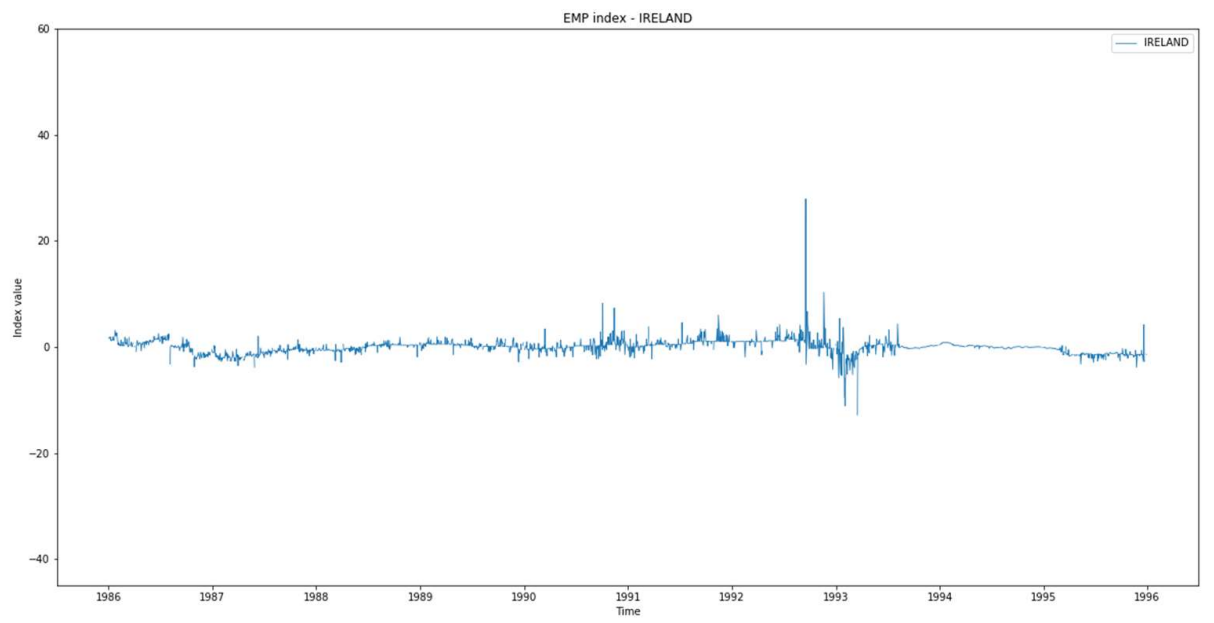


Figure B7. EMP index for the Netherlands

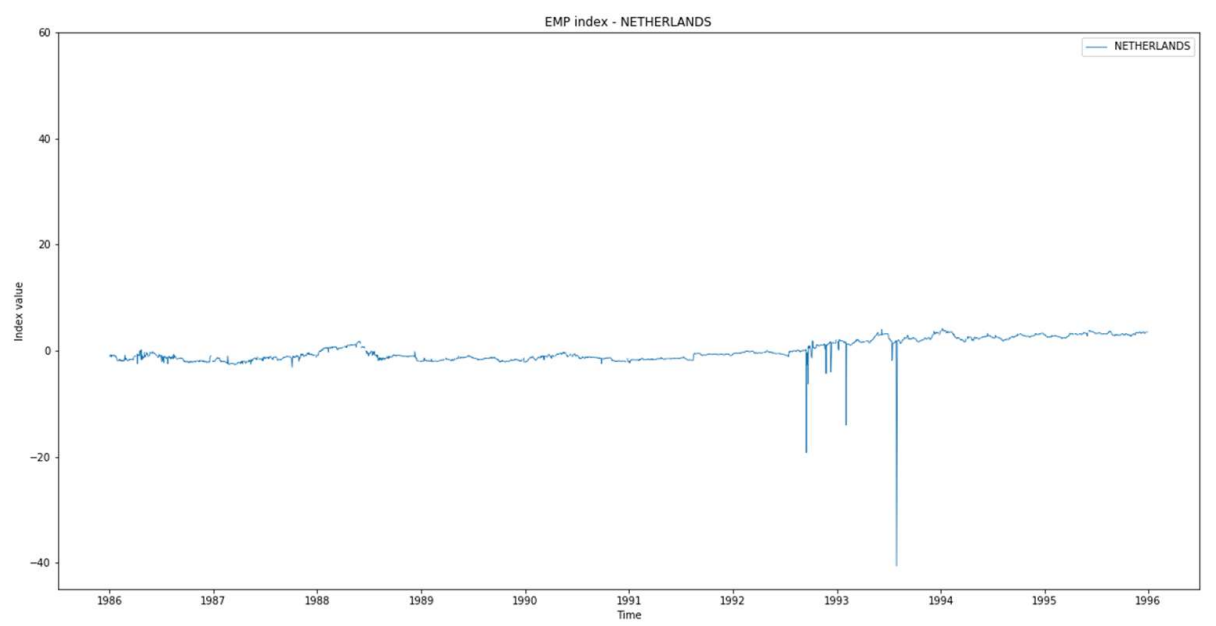

Figure B8. EMP index for Norway

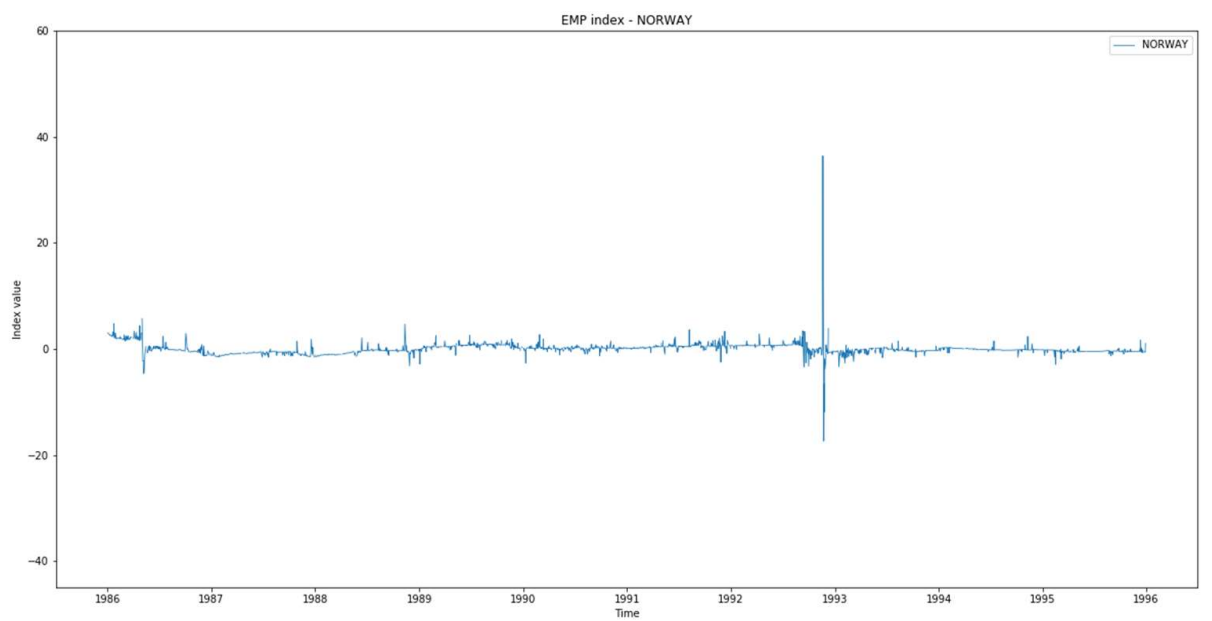


Figure B9. EMP index for Portugal

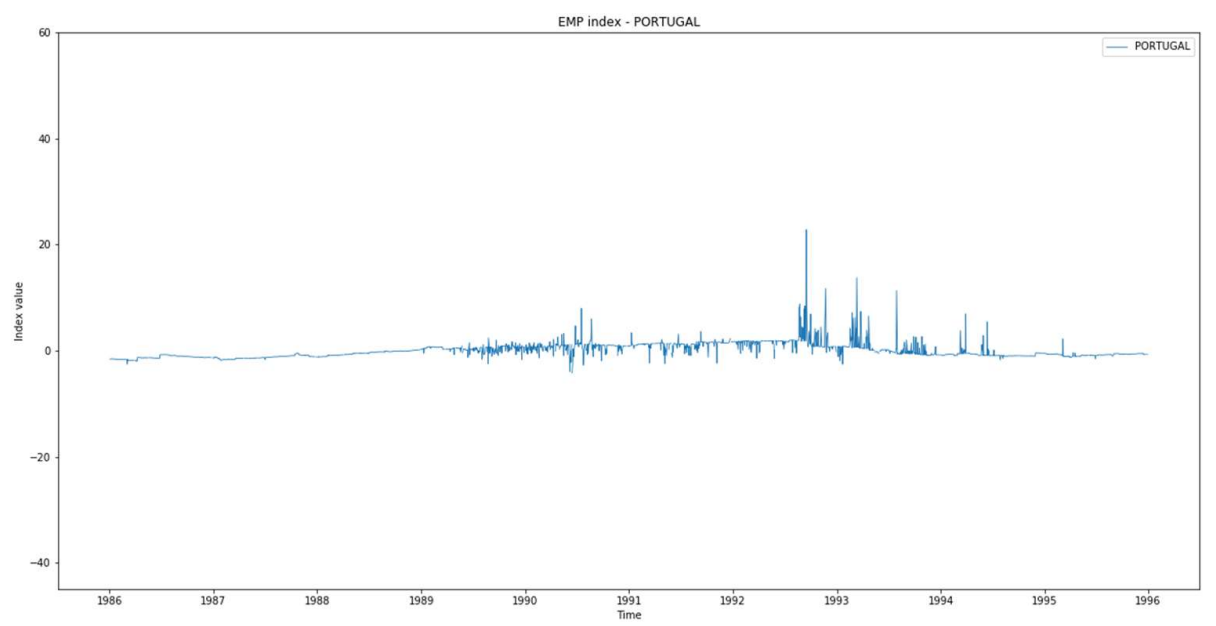

Figure B10. EMP index for Spain

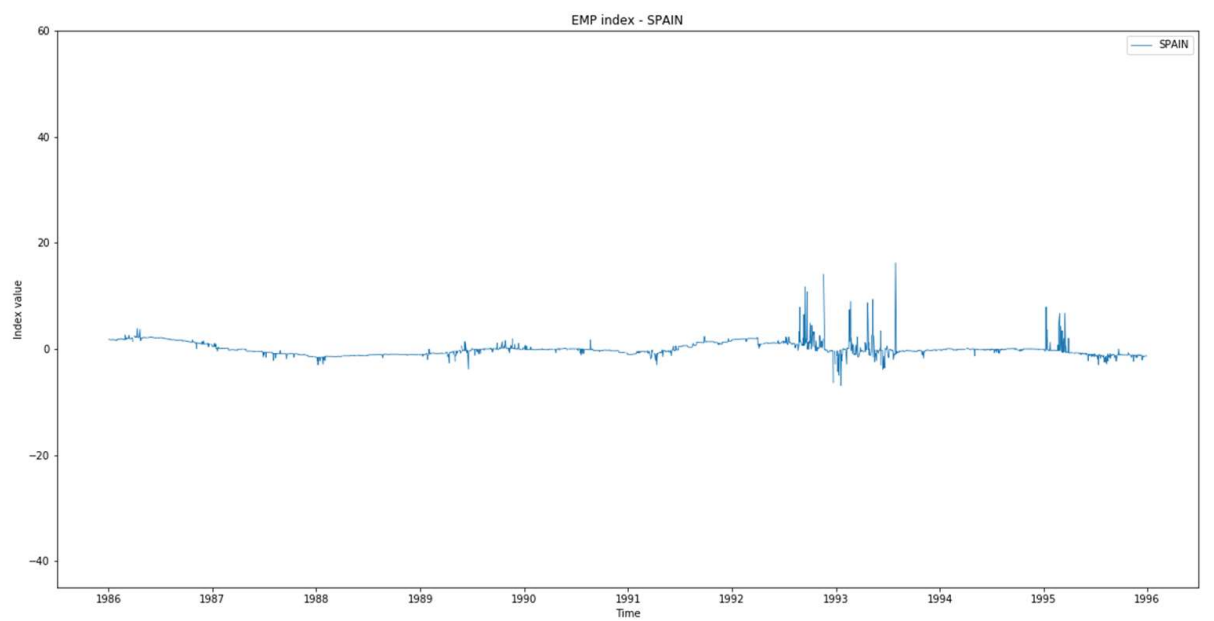


Figure B11. EMP index for Sweden

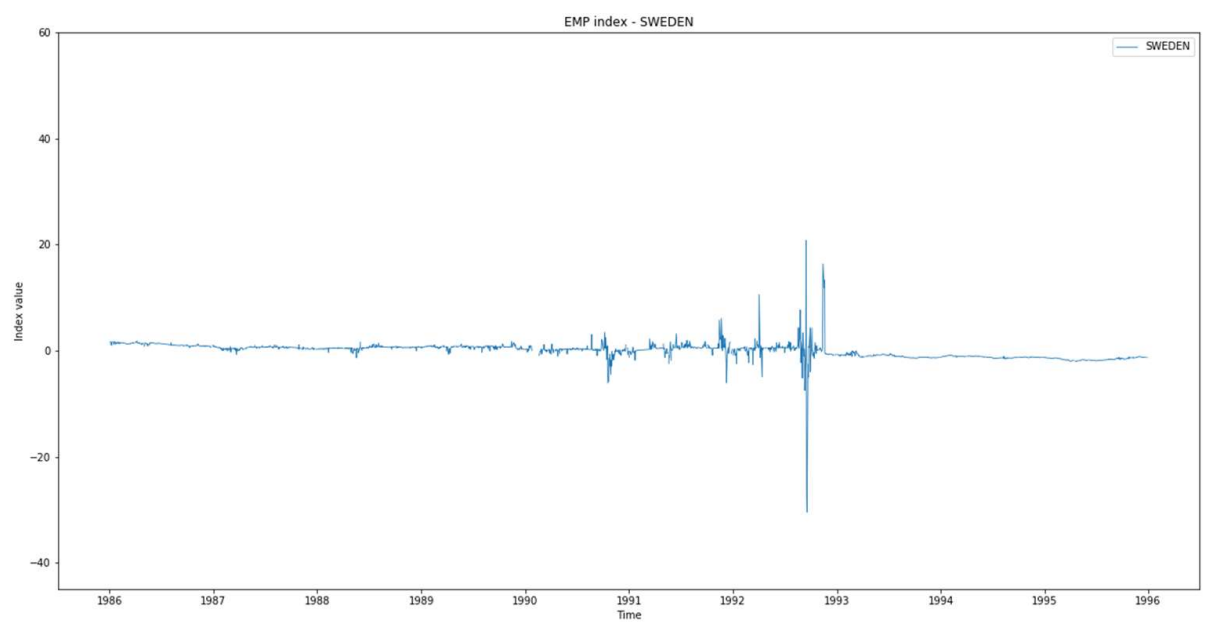

Figure B12. EMP index for the UK

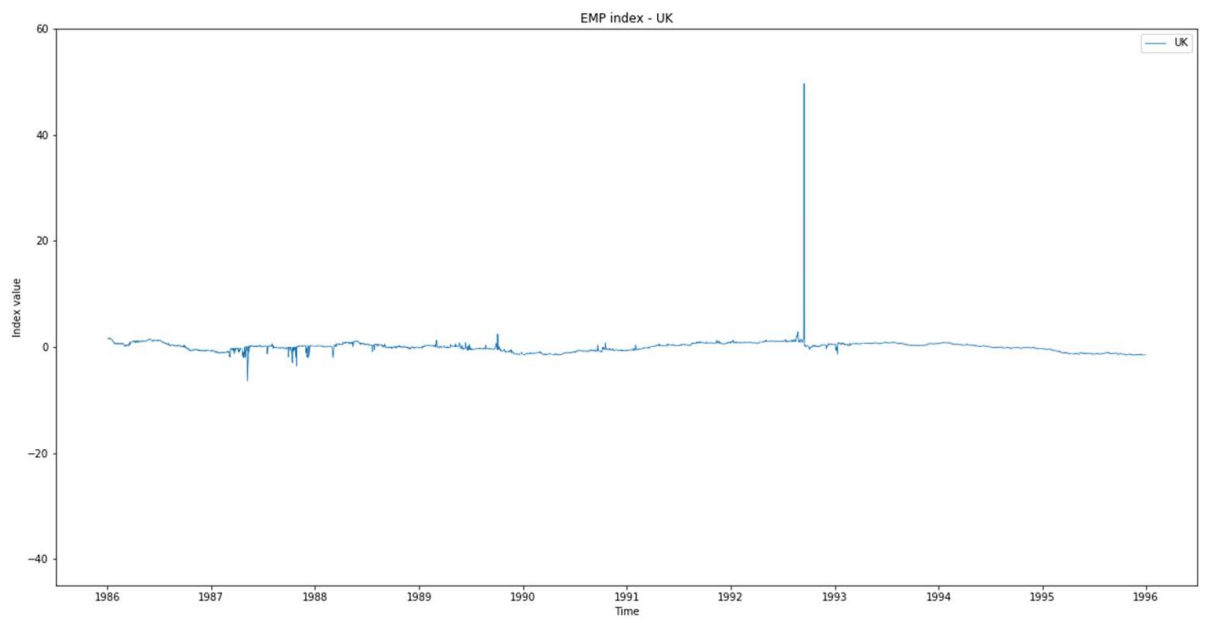




\section{Appendix C. Background on the EMS}

The Exchange Rate Mechanism (ERM) of the European Monetary System (EMS) was a system of currency bands established in 1979 to limit currency-related tensions and foster monetary integration.$^{87}$ It succeeded an earlier European arrangement, the Snake, whose operation was less satisfactory. ${ }^{88}$

The ERM committed central banks to maintain central parities surrounded by $2^{1 / 4}$ per cent fluctuation bands. New members who joined subsequently, such as the UK, Ireland and Portugal, were obliged to keep their currencies within $+/-6$ per cent bands vis-a-vis those of other members, with the expectation that they would eventually move to narrow $+/-21 / 4$ per cent bands. Although all currencies were formally pegged to the European Currency Unit, or ecu, in practice the DM was the anchor of the system, since it was the strongest currency and was expected to remain so (Giovannini 1989, Abdelal 1998). The task for other central banks thus became to adjust interest rates and policies to conform to those of the Bundesbank.

When negotiating the EMS agreement in 1978-9, German officials sought to strengthen the incentive for weak-currency countries to adjust their parities and policies, while their French counterparts pushed for more extensive foreign support. Both sides had to compromise. Germany dropped its proposal for obligatory adjustments in domestic policies, while France deferred its proposal for a European Monetary Fund to manage the combined foreign-exchange reserves of the participating countries and intervene in foreign exchange markets. ${ }^{89}$ Although the EMS Act of Foundation spoke of foreign support "unlimited in amount," German officials worried that such support would encourage lax policies and be an engine of inflation. An exchange of letters between the German finance minister and Bundesbank President Otmar Emminger therefore affirmed that the German central bank was entitled to opt out of its intervention obligation in the absence of what it judged to be appropriate adjustments by foreign central banks participating in the system..$^{90}$

No EMS member was forced to abandon the system prior to 1992. Instead, parities were modified periodically to eliminate imbalances and vent the pressure on weak currencies. Parity realignments occurred once every eight months on average in the first four years of the EMS.

\footnotetext{
${ }^{87}$ European officials were keen to limit variability, given their recollections of disruptive exchange rate changes in the 1930s and the perception that haphazard currency adjustments might cause trade-related dislocations within the European Economic Community and fan opposition to the Single Market. There was also the technical and political difficulty of operating the Common Agricultural Policy, with its domestic-currency-denominated support prices, in an environment of variable exchange rates. See Gros and Thygesen (1992).

${ }^{88}$ The Snake suffered from a variety of problems. Energy and commodity market shocks starting in 1973 affected different currencies differently, given that reliance on imported petroleum and commodities varied by country. Domestic policy adjustments and foreign support for weak-currency countries failed to eliminate the resulting imbalances. As yet, there was no consensus that monetary policy should be directed toward the maintenance of specific goals, price- and exchange-rate stability for example. And the European Monetary Cooperation Fund through which participants in the Snake were supposed to provide mutual assistance possessed limited resources and authority. ${ }^{89}$ Technically, France only deferred its proposal for this institution for two years, but the second oil shock quickly put paid to its ambitions.

${ }^{90}$ This note, known as the Emminger Letter, is discussed in Eichengreen and Wyplosz (1993). We return to it below.
} 
This recourse to periodic realignments was facilitated by restrictions on cross-border financial transactions. These capital controls limited the scope for speculators to sell a weak currency if they got wind of a government's realignment intentions. It was therefore possible for governments to discuss and organize realignments without precipitating a crisis.

This changed with the agreement in 1986 to create, within six years, a Single Market with free movement of goods, services, labor and, most consequentially in this context, financial capital. European governments were obliged to relax and remove their controls, consistent with this fourth freedom, which allowed growing volumes of capital to flow across borders. ${ }^{91}$ Even raising the possibility of currency realignments became problematic, since such talk might cause capital to flow out of the currency to be realigned downward, producing a self-fulfilling prophecy.

The period from 1987 through 1991 thus saw only two realignments: a last general realignment in January 1987, when capital controls were still prevalent, and a quasi realignment of the Italian lira in January 1990, which really only entailed Italy moving from the wide to the narrow band. This record was seen as evidence of success. It made the EMS attractive as an anchor for additional central banks. Finland, Sweden and Norway adopted pegs to the ecu or the DM to anchor their monetary policies. ${ }^{92}$

Whether this stability could be maintained in an environment of high capital mobility was uncertain, however, a problem that did not escape the attention of European leaders. Their response was the Delors Committee, which drafted the blueprint for the transition to a single European currency that became the Maastricht Treaty in February 1992, when political leaders endorsed the Committee's vision at a summit in the eponymous Dutch town. ${ }^{93}$

According to the treaty, countries had to keep their currencies stable within the ERM, without "undue pressure" and satisfy a set of other criteria in order to qualify for participation in the monetary union to come into existence by 1999. So long as the transition to a single European currency remained on course, governments and central banks, seeking to participate in Europe's signature project, had an incentive to pursue policies, however difficult and painful, designed to hold their currencies stable and gain admission to the club. Conversely, anything casting doubt on the inevitability of that project could raise questions about their commitment to such policies.

It was left only for European publics and their elected representatives to ratify the Maastricht Treaty. But European publics had qualms about replacing their national currencies with a single European unit and ceding control of monetary policy to a European central bank.

These ratification debates took place against the backdrop of German reunification, which occurred in 1990 and was relevant for two reasons. First, reunification implied increases in public

\footnotetext{
${ }^{91}$ There were still a few capital controls in countries with a history of currency weakness, Portugal and Ireland for example, but their presence did little to alter the story.

${ }_{92}$ They were not, however, formal members of the system, as noted above, and did not stand to receive support, financial or otherwise, from EMS central banks.

${ }^{93}$ More precisely, leaders met in Maastricht in December 1991; the signing session involving leaders, but also in some cases their delegates, was then in February 1992.
} 
spending on infrastructure and income support for the poor, often unemployed residents of Germany's new eastern lander. The resulting budget deficits fuelled inflation, causing the Bundesbank to raise its discount rate. ${ }^{94}$ In an environment of high capital mobility, other central banks had to follow suit or experience financial outflows and exchange-market pressure.

Second, German reunification created an additional argument for the Maastricht Treaty. A larger, more muscular Germany was perceived as potentially threatening its European neighbors (Berdahl 2005). Monetary unification, as an additional step in deepening the European Union, was a way of locking Germany peacefully into Europe (Bubow 2013). Relatedly, the leaders of other European countries, such as Francois Mitterrand of France, who desired monetary unification on other grounds, were able to secure German support for the initiative in return for acquiescing to reunification. ${ }^{95}$

${ }^{94}$ It did so in a series of 50-basis-point steps, from 6 per cent at the end of 1989 to 8 per cent at the end of 1991, and then by 75 basis points to 8.75 per cent in July 1992 .

${ }^{95}$ There is dispute over the explicitness of this linkage (Sauga, Simons and Wiegrefe 2010). 


\section{Appendix D. Additional Robustness Checks}

Table D1. Bivariate regression

\begin{tabular}{|c|c|c|c|}
\hline & $\begin{array}{c}\text { Average } \\
\text { EMP for } \\
\text { all } \\
\text { countries }\end{array}$ & $\begin{array}{l}\text { Number of } \\
\text { countries } \\
\text { intervening }\end{array}$ & $\begin{array}{c}\text { Average } \\
\text { DM } \\
\text { intervention }\end{array}$ \\
\hline Lagged change in exchange rate & $\begin{array}{c}-5.40^{* * *} \\
(2.22)\end{array}$ & $\begin{array}{c}-1.73^{* * *} \\
(0.32)\end{array}$ & $\begin{array}{c}11110 * * * \\
(3500)\end{array}$ \\
\hline $\mathrm{N}$ & 2342 & 2575 & 2575 \\
\hline $\mathrm{R}$ squared & 0.004 & 0.01 & 0.007 \\
\hline
\end{tabular}

Table D2. Same day exchange rate

\begin{tabular}{|c|c|c|c|}
\hline & $\begin{array}{l}\text { Average } \\
\text { EMP for } \\
\text { all } \\
\text { countries }\end{array}$ & $\begin{array}{l}\text { Number of } \\
\text { countries } \\
\text { intervening }\end{array}$ & $\begin{array}{c}\text { Average } \\
\text { DM } \\
\text { intervention }\end{array}$ \\
\hline Change in exchange rate & $\begin{array}{c}-4.58^{* * *} \\
(1.26)\end{array}$ & $\begin{array}{c}-1.30^{* * *} \\
(0.26)\end{array}$ & $\begin{array}{l}5387^{* *} \\
(2575)\end{array}$ \\
\hline $\begin{array}{l}\text { Control: Lagged change in interest } \\
\text { differential (Germany-US) }\end{array}$ & $\begin{array}{c}0.04 \\
(0.03)\end{array}$ & $\begin{array}{c}0.009 \\
(0.004)\end{array}$ & $\begin{array}{l}-162.38 \\
(77.84)\end{array}$ \\
\hline $\begin{array}{l}\text { Day of the week, month and year } \\
\text { control }\end{array}$ & yes & yes & yes \\
\hline $\mathrm{N}$ & 2345 & 2572 & 2571 \\
\hline $\mathrm{R}$ squared & 0.59 & 0.21 & 0.08 \\
\hline
\end{tabular}


Table D3. Monthly data

\begin{tabular}{llll}
\hline & $\begin{array}{l}\text { Average } \\
\text { EMP for } \\
\text { all } \\
\text { countries }\end{array}$ & $\begin{array}{l}\text { Number of } \\
\text { countries } \\
\text { intervening }\end{array}$ & $\begin{array}{l}\text { Average DM } \\
\text { intervention }\end{array}$ \\
\hline Change in exchange rate & $\begin{array}{l}-39.67^{*} \\
(21.35)\end{array}$ & $\begin{array}{l}-139.15^{* *} \\
(64.86)\end{array}$ & $\begin{array}{l}683^{\prime} 767.5^{*} \\
\left(389^{\prime} 556.6\right)\end{array}$ \\
& $0.18^{* * *}$ & $0.34^{* * *}$ & $-2188.16^{* *}$ \\
Germany interest rate & $(0.03)$ & $(0.11)$ & $(1103.37)$ \\
Interest differential (Germany- & -0.02 & -3.59 & 54364.06 \\
US) & $(0.77)$ & $(2.91)$ & $(52304.58)$ \\
\hline $\mathrm{N}$ & 120 & 120 & 120 \\
$\mathrm{R}$ squared & 0.44 & 0.11 & 0.24 \\
\hline
\end{tabular}

For exchange rates, interest rates and EMP, these are current average monthly values. For interventions amounts and number of countries intervening we take the aggregate sum of intervention and number of countries for a month. We also drop day of the week, week of the month, and month of the year dummies.

Standard errors reported are estimated using heteroscedasticity and autocorrelation-consistent (HAC) estimators with a Newey-West correction. ${ }^{* * *}$ signifies statistically significant at the $1 \%$ level of significance; ${ }^{* *}$ at the $5 \%$ level of significance; ${ }^{*}$ at the $10 \%$ level of significance.

Table D4. EMP Model: Coefficient on dollar/DM rate, individual European currencies

\begin{tabular}{lc} 
& Coefficient (SE) \\
\cline { 2 - 2 } Belgium & $-9.08(4.90)^{*}$ \\
Denmark & $-4.79(4.40)$ \\
Finland & $-6.23(3.73)^{*}$ \\
France & $-3.04(3.21)$ \\
Ireland & $-10.34(4.44)^{* *}$ \\
Italy & $-10.39(5.03)^{* * *}$ \\
Netherlands & $-2.22(4.87)$ \\
Norway & $-9.97(6.58)$ \\
Portugal & $0.05(4.19)$ \\
Spain & $-6.75(4.22)$ \\
Sweden & $-0.01(0.12)$ \\
UK & $2.94(3.34)$
\end{tabular}

Note : Specification follows Table 8. This table shows the coefficient of interest (on the dollar/DM rate) from 12 separate regressions for the 12 countries listed. Results are identical when we instead estimate the model in Table 7. 
Table D5. EMP Model: Coefficient on dollar/DM rate interacted with proximity to edge of the currency-specific fluctuation band

\begin{tabular}{lc} 
& Coefficient (SE) \\
\cline { 2 - 2 } Belgium & $-11.80(8.79)$ \\
France & $-8.86(11.23)$ \\
Ireland & $-59.84(33.35)^{*}$ \\
Italy & $-25.98(26.14)$ \\
Netherlands & $-11.49(29.61)$ \\
Portugal & $57.65(58.13)$ \\
Spain & $-32.31(11.91)^{* * *}$ \\
UK & $57.46(56.30)$
\end{tabular}

Note : Specification follows Table 8. For further discussion, see text.

Table D6 EMP Estimates Using Girton-Roper Weights: Impact of change in dollar/DM exchange rate, German interest rate and interest differential

\begin{tabular}{ll}
\hline & $\begin{array}{l}\text { Girton- } \\
\text { Roper } \\
\text { EMP for } \\
\text { all } \\
\text { countries }\end{array}$ \\
& $\begin{array}{l}-1095.6^{* * *} \\
(316.7)\end{array}$ \\
\hline Lagged change in exchange rate & $7.81^{* *}$ \\
& $(3.95)$ \\
Lagged German interest rate & 3.66 \\
& $(5.55)$ \\
Lagged interest rate differential & \\
(Germany-US) & \\
& \\
Day, month and year controls & \\
\hline N & 2187 \\
R squared & 0.09 \\
\hline
\end{tabular}

Standard errors reported are estimated using heteroscedasticity and autocorrelation-consistent (HAC) estimators with a Newey-West correction. ${ }^{* * *}$ signifies statistically significant at the $1 \%$ level of significance; ** at the $5 \%$ level of significance; ${ }^{*}$ at the $10 \%$ level of significance. We drop three outliers when intervention is above $\$ 15$ billion. 
Figures 5 and 6 show separate periods of trend weakening (strengthening) of the dollar against the DM. It is possible that changes in the dollar/DM rate affect exchange market pressure more strongly in periods of trend depreciation when the attention of market participants was drawn to the problem. To analyze this possibility, we create dummy variables for trend depreciation and trend appreciation periods. These trends are calculated from peak to trough for downward trends, and then trough to peak for upward trends. ${ }^{96}$ We also create analogous variables for trend increase and decrease periods for both the German interest rate and the Fed funds rate. We then run the same regression as in Table 6 with the addition of the Fed funds rate, but this time interacting the independent variables with these trend dummies.

$$
\begin{gathered}
E M P_{t}=\beta_{0}+\beta_{1}\left(F x_{t-1}-F x_{t-2}\right) \times F X_{\text {down }}+\beta_{2}\left(F x_{t-1}-F x_{t-2}\right) \times F X_{u p}+\beta_{3} R_{t-1}^{G E R} \times R_{\text {down }}^{G E R} \\
+\beta_{4} R_{t-1}^{G E R} \times R_{u p}^{G E R}+\beta_{5} R_{t-1}^{F e d} \times R_{\text {down }}^{F E D}+\beta_{6} R_{t-1}^{F e d} \times R_{u p}^{F E D}+\epsilon_{t}
\end{gathered}
$$

where $E M P_{t}$ is the average EMP index for EMS countries. $F x_{t-1}-F x_{t-2}$ is the lagged change in the exchange rate, $R_{t-1}^{G E R}$ is the lagged level of German interest rates, and $R_{t-1}^{F e d}$ is the lagged Fed funds rate. These three explanatory variables are then interacted with their respective trend variable, $F X_{\text {down }}$. takes the value 1 when the dollar is depreciating against the DM. $F X_{\text {up }}$ takes the value 1 when the dollar is appreciating against the DM (in our argument, less pressure on ERM countries). $R_{u p}^{G E R}$ take the value 1 when the German interest rate is on an upward trend. $R_{\text {down }}^{G E R}$ takes the value 1 when the German interest rate is on a downward trend. And finally, $R_{\text {down }}^{F E D}$ is 1 for downward trends on the Fed funds rate, $R_{u p}^{F E D}$ is 1 for upward trends to the Fed funds rate.

\section{Table D7. Pressure regressions with trend elements}

\begin{tabular}{ll}
\hline & \\
& $\begin{array}{c}\text { Average EMP } \\
\text { for all countries }\end{array}$ \\
\hline Lagged German interest rate (German rate on downward trend) & $0.01(0.02)$ \\
Lagged German interest rate (German rate on upward trend) & $0.05(0.009)^{* * *}$ \\
Lagged change in exchange rate (dollar on downward trend) & $-6.97(2.42)^{* * *}$ \\
Lagged change in exchange rate (dollar on upward trend) & $-0.94(6.09)$ \\
Lagged Fed funds rate (Fed funds rate on downward trend) & $-0.10(0.01)^{* * *}$ \\
Lagged Fed funds rate (Fed funds rate on upward trend) & $-0.07(0.02)^{* * *}$ \\
\hline $\mathrm{N}$ & \\
\hline
\end{tabular}

${ }^{96}$ Peak and trough dates available from the authors on request. 
The results show that the dollar/DM rate has a significant impact only when the exchange rate is trending downward. Note that this was the case in the year leading up to the ERM crisis that is at the heart of this paper. In addition, higher German interest rates contribute more to EMP than lower rates do to relieve it. Interestingly, higher U.S. rates reduce EMP in Europe, the opposite of their impact on emerging markets during the 2013 "taper tantrum." An interpretation is that higher U.S. rates led market participants to anticipate a stronger dollar going forward, and the dollar exchange rate was key in the EMS context owing to dollar/DM polarization.

Adding fixed effects does not alter the results.

Table D8. Impact of change in dollar/DM exchange rate distinguishing trend dollar/DM appreciation and depreciation periods (replication of Table 5)

\begin{tabular}{|c|c|c|c|}
\hline & $\begin{array}{l}\text { Average } \\
\text { EMP for all } \\
\text { countries }\end{array}$ & $\begin{array}{l}\text { Number of } \\
\text { countries } \\
\text { intervening }\end{array}$ & $\begin{array}{l}\text { Average DM } \\
\text { intervention }\end{array}$ \\
\hline $\begin{array}{l}\text { Lagged change in exchange } \\
\text { rate } \times \text { dollar depreciating } \\
\text { dummy }\end{array}$ & $\begin{array}{l}-5.66^{* * *} \\
(1.53)\end{array}$ & $\begin{array}{l}-1.83^{* * *} \\
(0.41)\end{array}$ & $\begin{array}{l}8470.4^{* * *} \\
(2716.0)\end{array}$ \\
\hline $\begin{array}{l}\text { Lagged change in exchange } \\
\text { rate } \times \text { dollar appreciating } \\
\text { dummy }\end{array}$ & $\begin{array}{l}-3.15 \\
(3.21)\end{array}$ & $\begin{array}{l}-1.36^{* * *} \\
(0.42)\end{array}$ & $\begin{array}{l}13829.5^{* *} \\
(6818.6)\end{array}$ \\
\hline $\begin{array}{l}\text { Lagged German interest } \\
\text { rate }\end{array}$ & $\begin{array}{l}0.24^{* * *} \\
(0.03)\end{array}$ & $\begin{array}{l}0.04^{* * *} \\
0.006\end{array}$ & $\begin{array}{l}-87.79 * * \\
(44.27)\end{array}$ \\
\hline $\begin{array}{l}\text { Day, month and year } \\
\text { controls }\end{array}$ & yes & Yes & yes \\
\hline $\mathrm{N}$ & 2342 & 2575 & 2575 \\
\hline $\mathrm{R}$ squared & 0.63 & 0.25 & 0.09 \\
\hline
\end{tabular}


Table D9. Impact of change in dollar/DM exchange rate distinguishing trend dollar/DM appreciation and depreciation periods (replication of Table 6)

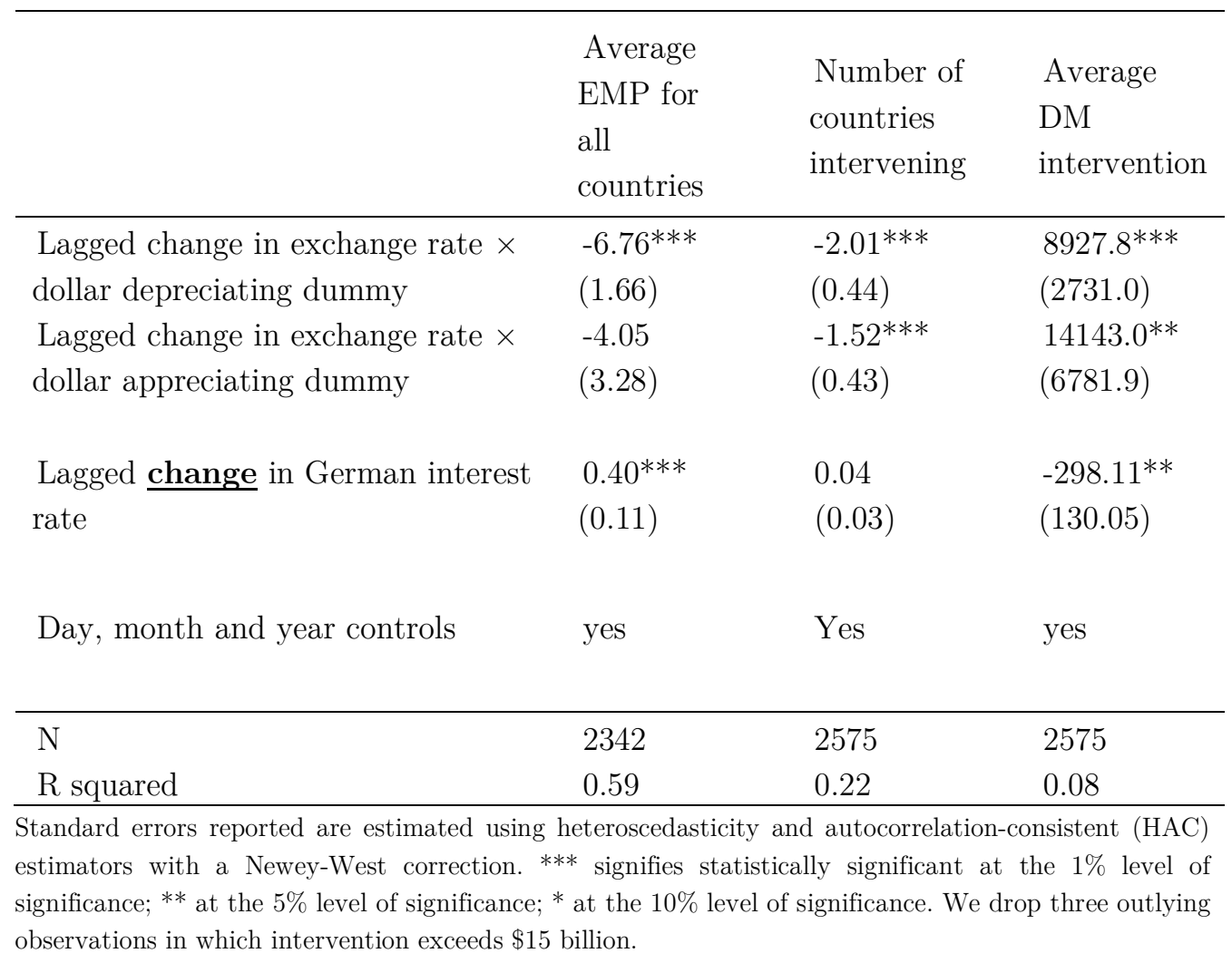

Alternatively, we can estimate regime-switching regressions. Here we use a Markov regimeswitching regression model. ${ }^{97}$ In the model, each day is considered separately and given a probability of being in Regime 1 or 2 so as to minimize the standard error of the model. The lagged EMP index is added as a non-switching coefficient. Here we specify two regimes (more is computationally challenging). Convergence was achieved after 30 iterations. $^{98}$

\footnotetext{
${ }^{97}$ Running it a simple non-Markov model yields similar regime probabilities, with only a slightly higher probability of being in the "crisis" regime.

${ }^{98}$ The statistical software does the iterative optimization using a Broyden-Fletcher-Goldfarb-Shanno (BFGS) algorithm.
} 
Figure D1. Regime switches

Probability of Regime 1

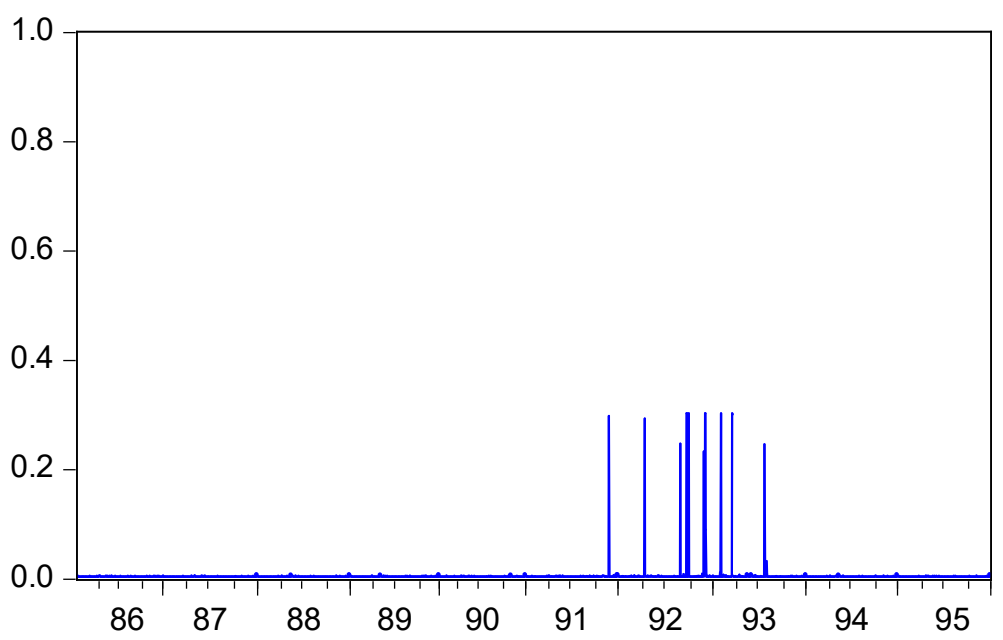

Probability of Regime 2

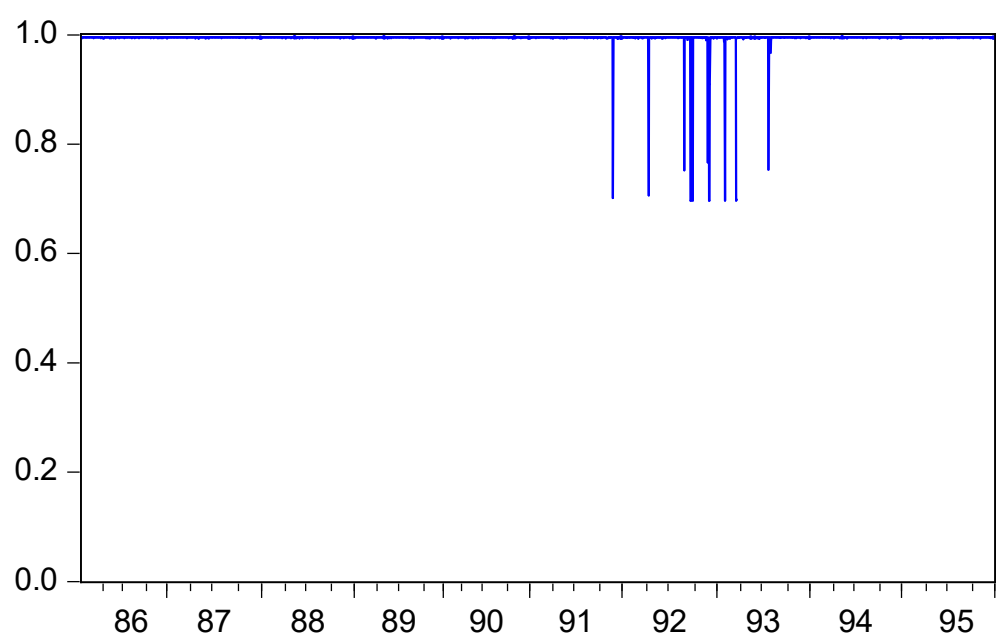

Figure D1 shows that the probability to being in Regime 1 is high mainly in 1992-93, and specifically in September 1992, around the time of Black Wednesday, in July 1993, during the attack on the franc. Table D10 shows that the dollar/DM rate displays larger coefficients during Regime 2 (the "crisis" regime). The coefficient in Regime 2 is larger than the estimated coefficients in EMP regressions presented in the paper. During key episodes of the ERM crisis, evidently, a fall of the dollar was particularly damaging to confidence in European currencies. Outside of the crisis period, the dollar/DM exchange rate is still significant and similar to the OLS coefficients reported in the text. 
Table D10. Regime switching regressions

\begin{tabular}{|c|c|}
\hline & $\begin{array}{l}\text { Average EMP } \\
\text { for all countries }\end{array}$ \\
\hline \multicolumn{2}{|c|}{ Regime 1 ("crisis" regime) } \\
\hline Lagged German rate & $\begin{array}{c}-1.70 * * * \\
(0.16)\end{array}$ \\
\hline Lagged rate differential & $\begin{array}{c}-13.55^{* * *} \\
(0.52)\end{array}$ \\
\hline Lagged USD-DM rate & $\begin{array}{c}-57.05^{* * *} \\
(9.62)\end{array}$ \\
\hline \multicolumn{2}{|c|}{ Regime 2 ("normal" regime) } \\
\hline Lagged German rate & $\begin{array}{c}0.048^{* * *} \\
(0.004)\end{array}$ \\
\hline Lagged rate differential & $\begin{array}{l}-0.017 \\
(0.022)\end{array}$ \\
\hline Lagged USD-DM rate & $\begin{array}{c}-2.44^{* * *} \\
(0.94)\end{array}$ \\
\hline \multicolumn{2}{|c|}{ Common factors } \\
\hline Lagged EMP index & $\begin{array}{l}0.72^{* * *} \\
(0.012)\end{array}$ \\
\hline $\mathrm{N}$ & 2179 \\
\hline Log likelihood & -336.09 \\
\hline $\begin{array}{l}\text { Note: Convergence was achieved } \\
\text { The definition of "crisis" and "no } \\
\text { for ease of reading. The regimes ar } \\
\text { D1. }\end{array}$ & $\begin{array}{l}\text { s. We impose } 2 \text { regimes } \\
\text { ralue judgement we ad } \\
\text { ee probabilities in Figur }\end{array}$ \\
\hline
\end{tabular}




\section{Appendix E. Local projections}

In addition to the OLS and VAR analyses reported in the text, we estimated our model by Jorda (2005) local projections. The following charts show impulse response function mirroring the VAR results in Figure 7. Our projections are run with 4 lags, as is standard, although removing or adding lags does alter affect the picture. The grey bands show a 95\% confidence interval. Endogenous variables are the dollar/DM exchange rate, the German interest rate, and one of EMP, number of interventions and intervention amounts.

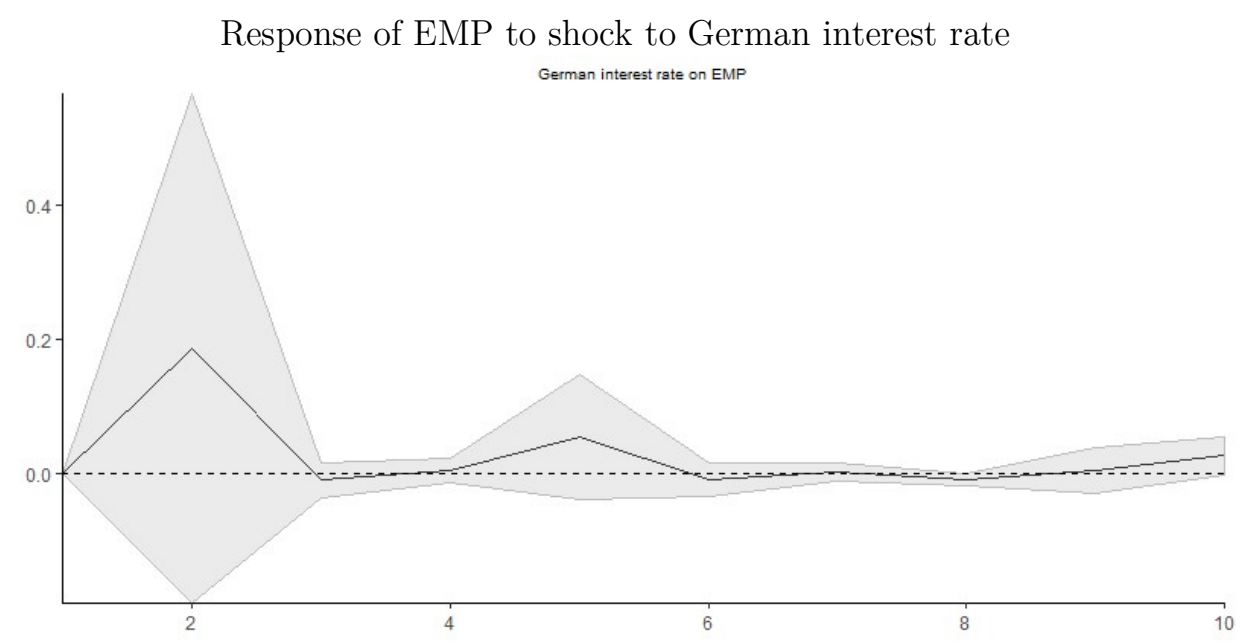

Response of EMP to shock to dollar/DM exchange rate

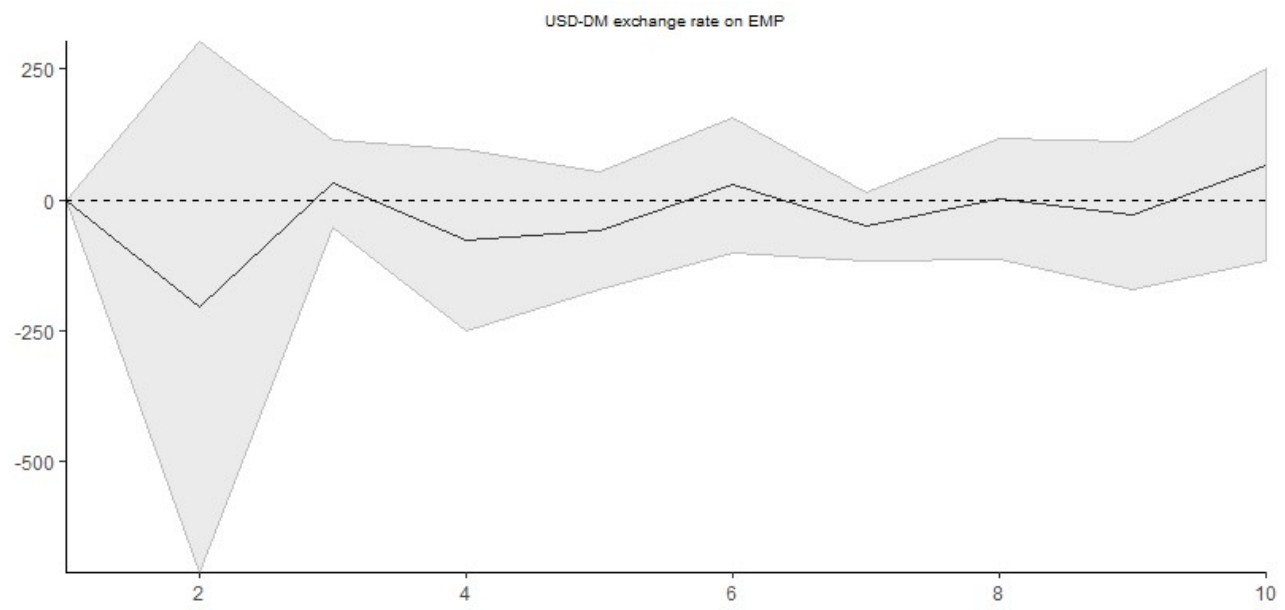


Response of number of central banks intervening to shock to German interest rate

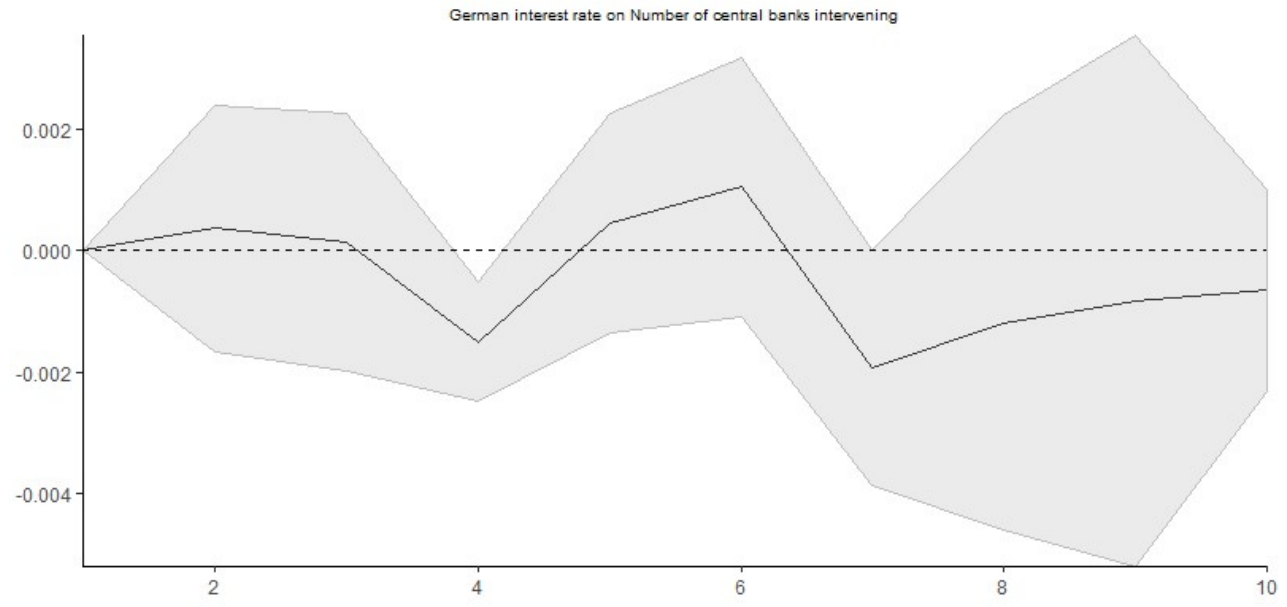

Response of number of central banks intervening to shock to dollar/DM exchange rate

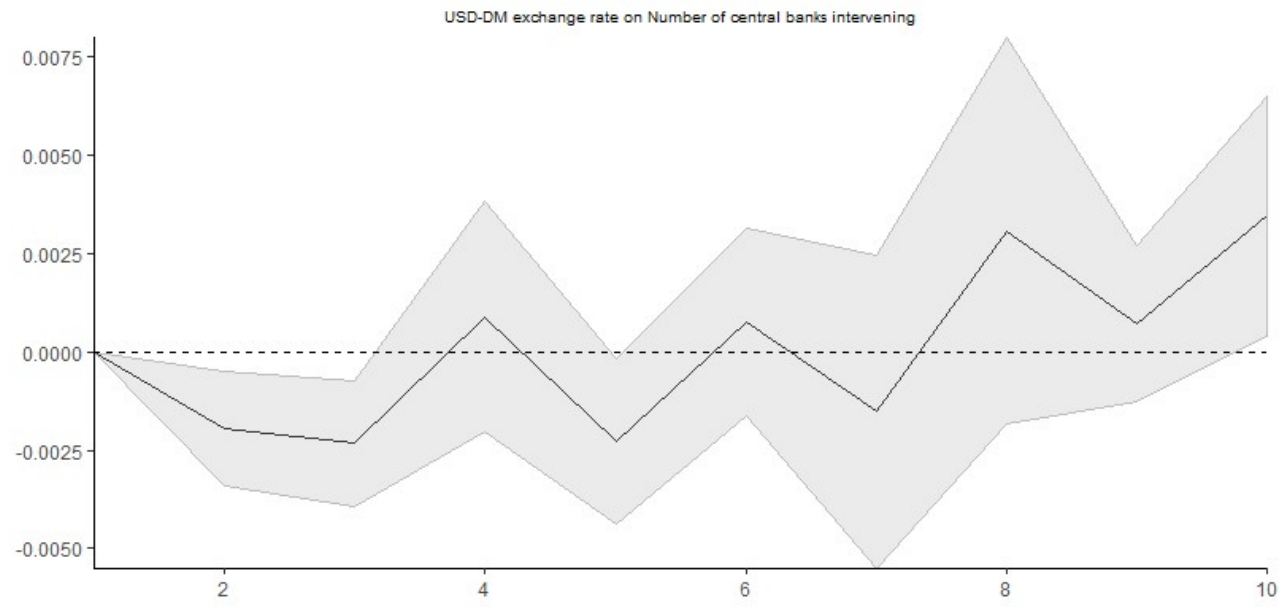


Response of amount of intervention to shock to German interest rate

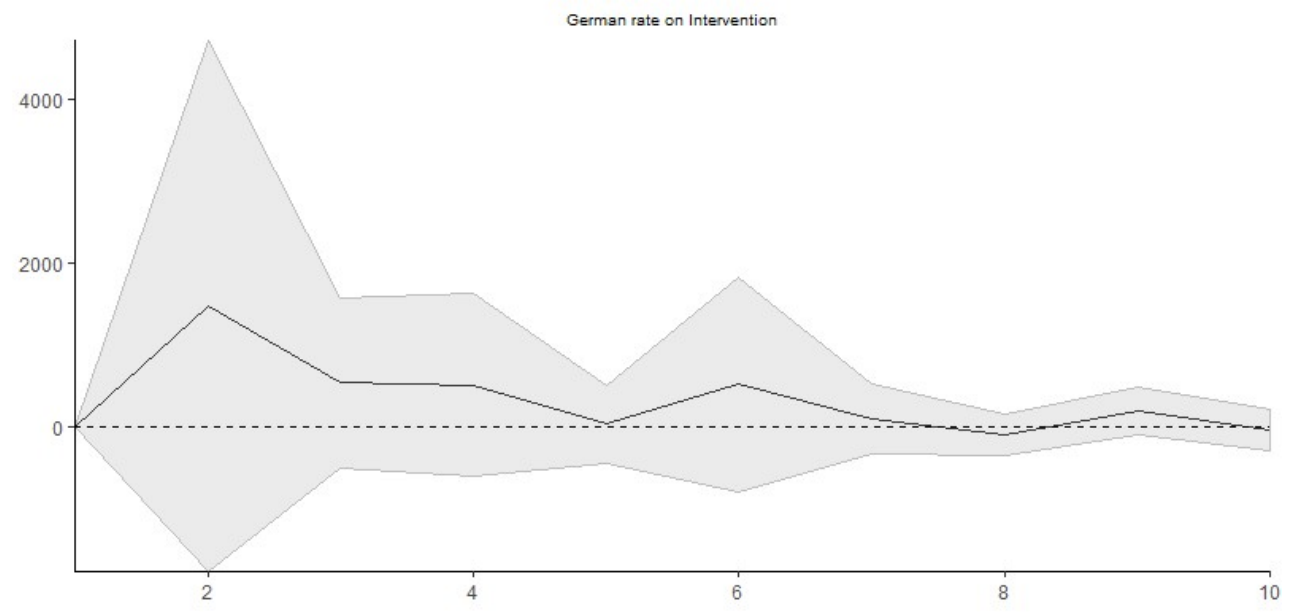

Response of the amount of intervention to shock to dollar/DM exchange rate

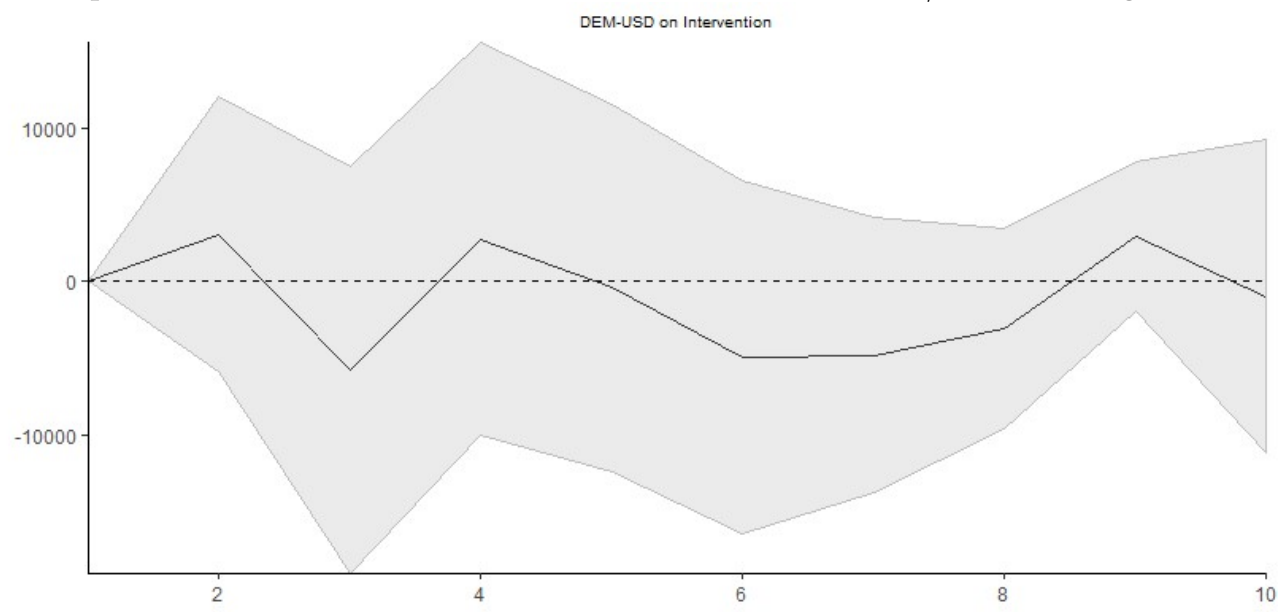

